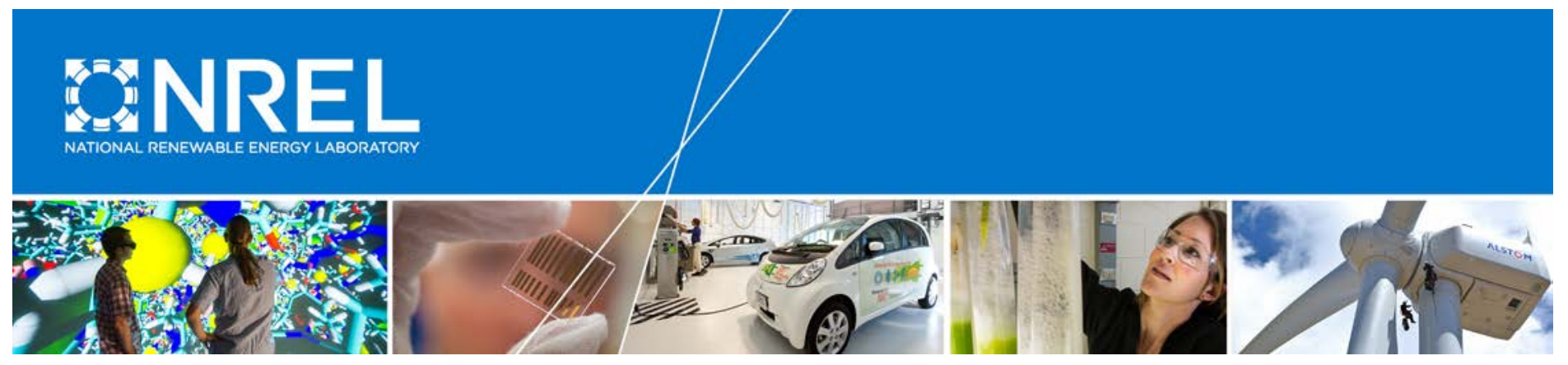

\title{
Fuel Cell Buses in U.S. Transit Fleets: Current Status 2017
}

Leslie Eudy and Matthew Post National Renewable Energy Laboratory

NREL is a national laboratory of the U.S. Department of Energy Office of Energy Efficiency \& Renewable Energy Operated by the Alliance for Sustainable Energy, LLC

This report is available at no cost from the National Renewable Energy Laboratory (NREL) at www.nrel.gov/publications.

Technical Report

NREL/TP-5400-70075

November 2017

Contract No. DE-AC36-08GO28308 


\section{Fuel Cell Buses in U.S. Transit Fleets: Current Status 2017}

Leslie Eudy and Matthew Post National Renewable Energy Laboratory

Prepared under Task No. FCHT.10266.04.01.01
NREL is a national laboratory of the U.S. Department of Energy Office of Energy Efficiency \& Renewable Energy Operated by the Alliance for Sustainable Energy, LLC

This report is available at no cost from the National Renewable Energy Laboratory (NREL) at www.nrel.gov/publications.
National Renewable Energy Laboratory 15013 Denver West Parkway Golden, CO 80401

303-275-3000 • www.nrel.gov
Technical Report

NREL/TP-5400-70075

November 2017

Contract No. DE-AC36-08GO28308 


\section{NOTICE}

This report was prepared as an account of work sponsored by an agency of the United States government. Neither the United States government nor any agency thereof, nor any of their employees, makes any warranty, express or implied, or assumes any legal liability or responsibility for the accuracy, completeness, or usefulness of any information, apparatus, product, or process disclosed, or represents that its use would not infringe privately owned rights. Reference herein to any specific commercial product, process, or service by trade name, trademark, manufacturer, or otherwise does not necessarily constitute or imply its endorsement, recommendation, or favoring by the United States government or any agency thereof. The views and opinions of authors expressed herein do not necessarily state or reflect those of the United States government or any agency thereof.

This report is available at no cost from the National Renewable Energy Laboratory (NREL) at www.nrel.gov/publications.

Available electronically at SciTech Connect http:/www.osti.gov/scitech

Available for a processing fee to U.S. Department of Energy and its contractors, in paper, from:

U.S. Department of Energy

Office of Scientific and Technical Information

P.O. Box 62

Oak Ridge, TN 37831-0062

OSTI http://www.osti.gov

Phone: 865.576.8401

Fax: 865.576.5728

Email: reports@osti.gov

Available for sale to the public, in paper, from:

U.S. Department of Commerce

National Technical Information Service

5301 Shawnee Road

Alexandria, VA 22312

NTIS http://www.ntis.gov

Phone: 800.553 .6847 or 703.605 .6000

Fax: 703.605.6900

Email: orders@ntis.gov 


\section{Acknowledgments}

This document includes results and experiences from several U.S. fuel cell electric bus evaluation projects. The DOE's Fuel Cell Technologies Office within the Office of Energy Efficiency and Renewable Energy and the Federal Transit Administration provided funding for this effort. NREL appreciates the active participation of our project partners. Contributors to this report included staff members of federal and state government agencies, manufacturing firms, and transit authorities. The authors especially thank the following individuals:

Salvador Llamas, Roland Fecteau, and Jose Vega, Alameda-Contra Costa Transit District

Tommy Edwards and Mike Hayes, SunLine Transit Agency

Analy Castillo, University of California at Irvine

Sue Zuhlke, Cliff Thorne, Bill Habibe, and Joseph Townsend, Orange County Transportation Authority

Kevin Arouca and Bryan Ross, Massachusetts Bay Transportation Authority

Jason Marcinkoski and James Alkire, U.S. Department of Energy

Sean Ricketson, U.S. Department of Transportation, Federal Transit Administration

Byron Somerville, Steve Potvin, and George Morales, Ballard Power Systems

Brian Bowers, Nuvera

Robert Devine and Yesh Premkumar, BAE Systems

Nico Bouwkamp, California Fuel Cell Partnership

Erik Bigelow and Jaimie Levin, Center for Transportation and the Environment

Matthew Jeffers, Chris Ainscough, and Jen Kurtz, National Renewable Energy Laboratory 


\section{Acronyms and Abbreviations}

AC Transit

AFCB

CARB

CEC

$\mathrm{CNG}$

dge

DOE

ENC

FCEB

FCH JU

FCPP

$\mathrm{ft}$

FTA

gge

$\mathrm{kg}$

MBRC

MBTA

mph

NFCBP

NREL

OCTA

OEM

SARTA

TIGGER

TRL

UCI

ZEBA
Alameda-Contra Costa Transit District

American Fuel Cell Bus

California Air Resources Board

California Energy Commission

compressed natural gas

diesel gallon equivalent

U.S. Department of Energy

ElDorado National-California

fuel cell electric bus

Fuel Cell and Hydrogen Joint Undertaking

fuel cell power plant

feet

Federal Transit Administration

gasoline gallon equivalent

kilograms

miles between roadcalls

Massachusetts Bay Transportation Authority

miles per hour

National Fuel Cell Bus Program

National Renewable Energy Laboratory

Orange County Transportation Authority

original equipment manufacturer

Stark Area Regional Transit Authority

Transit Investments for Greenhouse Gas and Energy

Reduction

technology readiness level

University of California at Irvine

Zero Emission Bay Area 


\section{Definition of Terms}

Availability: The number of days the buses are actually available compared to the days that the buses are planned for operation expressed as percent availability.

Balance of plant: The components of the fuel cell system — such as air compressor, fans, and pumps - that support the operation of the fuel cell stack.

Clean point: The starting point for the data analysis period. For each evaluation, NREL works with the project partners to determine a starting point—or clean point—-for the data analysis period. The clean point is chosen to avoid some of the early and expected operations problems with a new vehicle going into service, such as early maintenance campaigns. In some cases, reaching the clean point may require 3 to 6 months of operation before the evaluation can start.

Fast fill: Per the SAE International J2601/2 standard, a flow rate of 61 to 120 grams per second is considered a fast fill. Transit agencies have a goal of completing a full fill of a hydrogenfueled bus in 10 minutes or less.

Miles between roadcalls (MBRC): A measure of reliability calculated by dividing the number of miles traveled by the number of roadcalls. (Also known as mean distance between failures.) MBRC results in the report are categorized as follows:

- Bus MBRC: Includes all chargeable roadcalls. Includes propulsion-related issues as well as problems with bus-related systems such as brakes, suspension, steering, windows, doors, and tires.

- Propulsion-related MBRC: Includes roadcalls that are attributed to the propulsion system. Propulsion-related roadcalls can be caused by issues with the power system (fuel cell), batteries, and hybrid systems.

- Fuel-cell-system-related MBRC: Includes roadcalls attributed to the fuel cell power plant and balance of plant only.

Revenue service: The time when a vehicle is available to the general public with an expectation of carrying fare-paying passengers. Vehicles operated in a fare-free service are also considered revenue service.

Roadcall: A failure of an in-service bus that causes the bus to be replaced on route or causes a significant delay in schedule. The analysis includes chargeable roadcalls that affect the operation of the bus or may cause a safety hazard. Non-chargeable roadcalls can be passenger incidents that require the bus to be cleaned before going back into service or problems with an accessory such as a farebox or radio. 


\section{Executive Summary}

This report, published annually, summarizes the progress of fuel cell electric bus (FCEB) development in the United States and discusses the achievements and challenges of introducing fuel cell propulsion in transit. The report provides a summary of results from evaluations performed by the National Renewable Energy Laboratory (NREL). NREL considers these FCEB designs to be around technology readiness level (TRL) 7 to 8 , that is, full-scale validation in a relevant environment. At this point in development, capital and operating costs for FCEBs are still much higher than those of conventional diesel technology. This is to be expected considering diesel is a very mature technology (TRL 9) and FCEBs are still in the development stage. This annual status report combines results from all FCEB demonstrations, tracks the progress of the FCEB industry toward meeting technical targets (as shown in Table ES-1), documents the lessons learned, and discusses the path forward for commercial viability of fuel cell technology for transit buses. These data and analyses help provide needed information to guide future early-stage research and development.

The U.S. Department of Energy (DOE) and the U.S. Department of Transportation's Federal Transit Administration (FTA) have established performance and cost targets for FCEBs. These targets, established with industry input, include interim targets for 2016 and ultimate targets for commercialization. FCEB technology continues to show progress toward meeting technical targets for reliability and durability while also decreasing in cost. Table ES-1 summarizes the performance of the FCEBs in the report compared to these targets.

Table ES-1. Summary of FCEB Performance Compared to DOE/FTA Targets ${ }^{1}$

\begin{tabular}{|c|c|c|c|c|}
\hline & Units & $\begin{array}{l}\text { Current Status }{ }^{a} \\
\text { (Range) }\end{array}$ & $\begin{array}{c}2016 \\
\text { Target }^{1}\end{array}$ & $\begin{array}{l}\text { Ultimate } \\
\text { Target }^{1}\end{array}$ \\
\hline Bus lifetime & years/miles & $\begin{array}{c}0.7-7 / \\
16,900-189,000^{b}\end{array}$ & $12 / 500,000$ & $12 / 500,000$ \\
\hline Power plant lifetime ${ }^{c}$ & hours & $600-25,000^{\mathrm{b}, \mathrm{d}, \mathrm{e}}$ & 18,000 & 25,000 \\
\hline Bus availability & $\%$ & $42-93$ & 85 & 90 \\
\hline Fuel fills & per day & 1 & $1(<10 \mathrm{~min})$ & 1 (<10 min) \\
\hline Bus cost $t^{g}$ & $\$$ & $\begin{array}{l}1,800,000- \\
2,400,000^{\mathrm{h}} \\
\end{array}$ & $1,000,000$ & 600,000 \\
\hline $\begin{array}{l}\text { Roadcall frequency } \\
\text { (bus/fuel cell system) }\end{array}$ & $\begin{array}{c}\text { miles between } \\
\text { roadcalls }\end{array}$ & $\begin{array}{l}1,100-8,700 / \\
7,600-23,700 \\
\end{array}$ & $\begin{array}{l}3,500 / \\
15,000 \\
\end{array}$ & $\begin{array}{l}4,000 / \\
20,000 \\
\end{array}$ \\
\hline Operation time & $\begin{array}{l}\text { hours per dayl } \\
\text { days per week }\end{array}$ & $\begin{array}{c}7-21 / \\
5-7 \\
\end{array}$ & $20 / 7$ & $20 / 7$ \\
\hline $\begin{array}{l}\text { Scheduled and } \\
\text { unscheduled } \\
\text { maintenance cost }\end{array}$ & \$/mile & $0.49-2.42$ & 0.75 & 0.40 \\
\hline Rangej & miles & $277-357$ & 300 & 300 \\
\hline Fuel economy & $\begin{array}{l}\text { miles per diesel } \\
\text { gallon equivalent }\end{array}$ & $5.83-7.82$ & 8 & 8 \\
\hline
\end{tabular}

\footnotetext{
${ }^{1}$ Fuel Cell Technologies Program Record \# 12012, September 12, 2012, www.hydrogen.energy.gov/pdfs/12012_fuel_cell_bus_targets.pdf.
} 


\footnotetext{
a The summary of results in this report represents data from the included demonstrations: from the beginning of each demonstration through July 2017.

${ }^{b}$ Accumulated totals for existing fleet through July 2017; these buses have not reached end of life.

${ }^{c}$ For the DOE/FTA targets, the power plant is defined as the fuel cell system and the battery system. The fuel cell system includes supporting subsystems such as the air, fuel, coolant, and control subsystems. Power electronics, electric drive, and hydrogen storage tanks are excluded.

${ }^{d}$ The status for power plant hours is for the fuel cell system only; battery lifetime hours were not available.

e The highest-hour power plant was transferred from an older-generation bus that had accumulated more than 6,000 hours prior to transfer.

${ }^{f}$ Multiple sequential fuel fills should be possible without an increase in fill time.

9 Cost targets are projected to a production volume of 400 systems per year. This production volume is assumed for analysis purposes only and does not represent an anticipated level of sales.

${ }^{\mathrm{h}}$ Reported cost of most recent orders for FCEBs was $\$ 1.8$ million.

i Excludes mid-life overhaul of power plant.

j Based on fuel economy and $95 \%$ tank capacity.
}

DOE/FTA set an ultimate performance target of 4 to 6 years (or 25,000 hours) durability for the fuel cell propulsion system, with an interim target of 18,000 hours by 2016 . The fuel cell power plants (FCPPs) tracked by NREL continue to accumulate significant numbers of hours. NREL has now collected data on buses for more than half their useful life -6 years. Last year's report documented a single FCPP surpassing 23,000 hours without repair or cell replacement. At the end of the analysis period for this report (July 2017), that FCPP had surpassed the ultimate target of 25,000 hours. Nine FCPPs have now surpassed the 2016 DOE/FTA target of 18,000 hours and six have reached 20,000 hours. The average for the group was 14,309 hours. Other projects outside the U.S. are also reporting fuel cell hours beyond the ultimate target.

Availability for the FCEBs ranges from a low of $42 \%$ to a high of $93 \%$ with an overall average of $75 \%$. Bus-related problems - such as brakes, suspension, air system, and air conditioningmake up the majority of unavailable days (45\%). Fuel cell system issues make up $27 \%$ of the unavailable time. Hybrid system problems - including issues with components such as traction motor, cooling system, and inverters - make up 15\% of the unavailable days. Unavailability of parts has resulted in extended downtime in some cases. Transit staff continues to learn about the systems and become more proficient in troubleshooting and repairing issues. Downtime is expected to decrease over time.

The targets for roadcall frequency include miles between roadcalls (MBRC) for the entire bus and MBRC for the fuel cell system only. The fuel cell system MBRC includes any roadcalls due to issues with the fuel cell stack or associated balance of plant. The overall MBRC was 4,648 for the bus and 21,255 for the fuel cell system. Bus MBRC continues to show a general upward trend since surpassing the ultimate target around May 2015. Fuel cell system MBRC continues to show an upward trend over time, surpassing the ultimate target in early 2015. Several fuel-cellrelated roadcalls in 2016 and early 2017 caused this number to drop; however, it is still over the ultimate target. Over the last 6 months, the fuel cell system MBRC is increasing. 
In past reports, NREL has included the in-use fuel economy to determine the status for this metric. Over time, the fuel economy had dropped for the older buses. This is typical for any vehicle as it ages. While the primary driver for the decreasing fuel economy is aging of the bus and components, other factors also play a role. Changes in duty cycle, drivers, and weather also factor into the equation. To better assess the status and capability of the buses, NREL has analyzed the early results for the FCEBs when they were first placed into service. For this analysis, we used the first full year of data from each demonstration to determine an average fuel economy. Because fuel economy is highly variable by duty cycle, NREL calculated an average fuel economy for each demonstration as opposed to one average for a particular FCEB design. NREL also analyzed the fuel economy for the earlier-generation buses. The fuel economy varied much more for the first-generation buses than for the second-generation buses. The average fuel economy for second-generation buses was 19\% higher than the average fuel economy for the first-generation buses. NREL used the fuel economy numbers and useful fuel amount $(95 \%$ of the tank's capacity) to calculate an estimated average range for the second-generation buses of approximately 300 miles.

FCEB performance continues to improve; however, there are still challenges to overcome to make the technology commercially viable. Challenges include the following:

Parts supply - Transit agencies continue to experience some issues with availability of bus components that have a long lead time for delivery. While this has improved for some components, agencies have taken the initiative to find other methods to supply parts including ordering parts directly from the component manufacturer or fabricating parts internally to reduce cost and downtime. This is particularly an issue for AC Transit because an original equipment manufacturer (OEM) outside the United Sates produced its FCEBs. Upcoming FCEB projects are purchasing buses built by North American OEMs using the same platform as conventional technologies. Sharing of conventional bus parts will help improve availability and lower parts costs.

Deployment of larger fleets - To date, the majority of demonstrations in the United States involve small numbers of buses. To commercialize the technology, future deployments need to increase in fleet size - especially for larger agencies. Large transit agencies experience significant challenges with operating one or only a few advanced technology buses that are different from its conventional fleets. It is hard to justify resources to train operators, mechanics, and schedulers to keep one unique bus in service. Any maintenance issue might result in the bus being parked until someone takes the time to troubleshoot and repair a problem, which may not be related to an advanced technology component. Operators have trouble remembering the different operating characteristics when they don't drive the bus often. Any agency without an internal champion for the technology will not get the same level of service from a new technology. This results in low mileage accumulation and availability. Deploying a larger fleet requires a commitment from all departments within an agency.

Maintenance costs for FCEBs - As reported last year, transit agencies operating FCEBs have made a concentrated effort to handle all the maintenance required for the buses. This results in a cost increase as transit staff takes on more of the maintenance responsibilities and begins the learning curve to understand how to maintain the buses. As the staff becomes more proficient, the costs eventually stabilize. The uncertainty for FCEBs at this point in development is how the 
parts costs will affect the overall maintenance costs over time once all the buses are out of the initial warranty period. To help with future planning, transit agencies need to understand future costs as the technology moves into early commercial deployment. Standardization and manufacturing processes could help lower costs for advanced-technology parts and components.

Competition with other zero-emission technologies-Early zero-emission demonstrations all involved FCEBs, primarily because the state of battery electric bus (BEB) technology at the time required overnight charging for a very limited range. Development of higher-energy-capacity traction battery designs improved significantly with the introduction of lithium-based batteries. The introduction of on-route charging and extended range batteries addressed concerns over lower range and long charge times. As a result, BEBs have made a surge into the market. Both $\mathrm{BEB}$ and FCEB technologies are viable options to meet emission reduction goals. Aggressive marketing by OEMs that only produce BEBs fuels the current push for batteries over fuel cells. In contrast, the OEMs that produce FCEBs also produce buses powered by all possible propulsion systems. The large numbers of BEBs in the United States compared to lower FCEB numbers may lead to an assumption that one technology had an advantage over the other. The fact that deployments in Europe, Japan, China, and Korea are focused on FCEBs indicates there is a market for both.

The 2017 summary results primarily focus on the most recent year for each demonstration, from August 2016 through July 2017. Previous status reports have referenced operational cost data from the individual project results reports. For this report, NREL has included an up-to-date analysis of operational costs including scheduled and unscheduled cost and cost per mile by system. NREL also provides historical data on the FCEBs and baseline buses to show cost trends over time. The primary results presented in the report are from five demonstrations of two different fuel-cell-dominant bus designs:

- Zero Emission Bay Area Demonstration Group led by Alameda-Contra Costa Transit District (AC Transit) in California

- American Fuel Cell Bus Project at SunLine Transit Agency in California

- American Fuel Cell Bus Project at the University of California at Irvine (UCI)

- American Fuel Cell Bus Project at Orange County Transportation Authority (OCTA)

- American Fuel Cell Bus Project at Massachusetts Bay Transportation Authority (MBTA)

NREL has a partial data set on the MBTA bus; therefore the analysis for that bus is limited to fuel cell system hours, miles accumulated, and fuel economy. 


\section{Table of Contents}

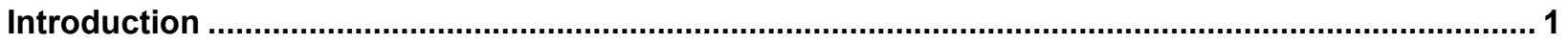

Scope and Purpose

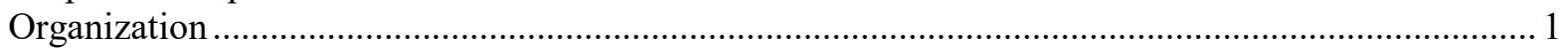

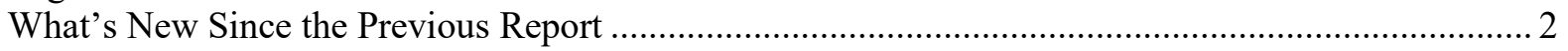

Fuel Cell Electric Buses in Operation in the United States ........................................................... 3

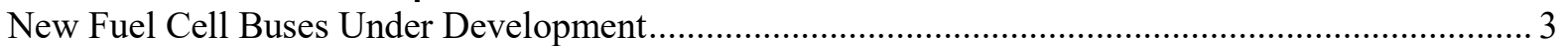

Fuel Cell Bus Demonstrations Outside North America ................................................................. 5

FCEB Development Process_Technology Readiness Levels ..................................................... 8

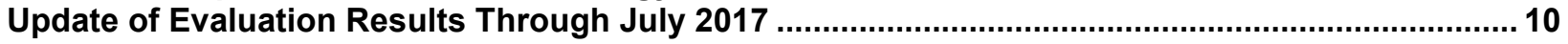

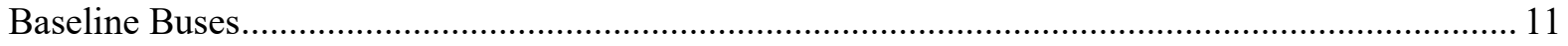

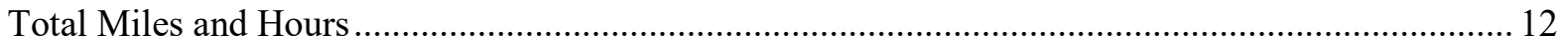

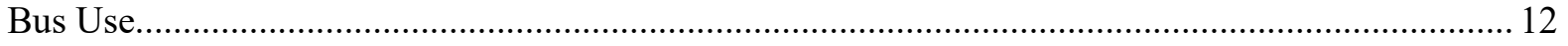

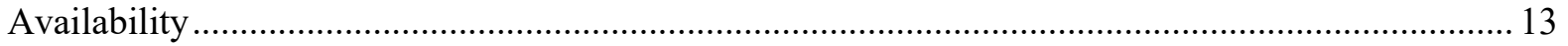

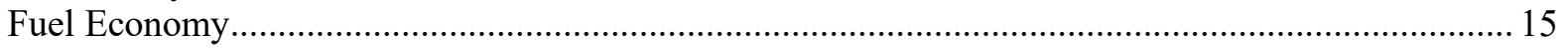

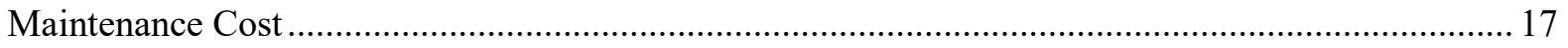

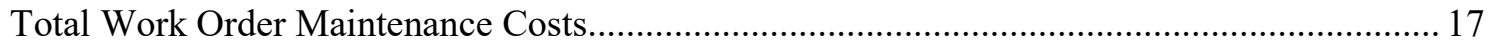

Work Order Maintenance Costs Categorized by System ....................................................... 20

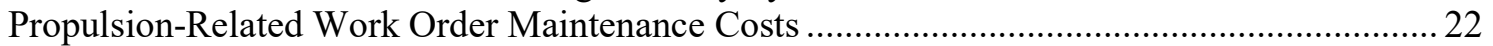

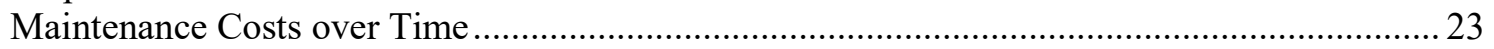

Current Status of FCEB Introductions: Summary of Achievements and Challenges ...................... 28

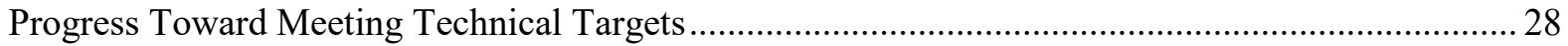

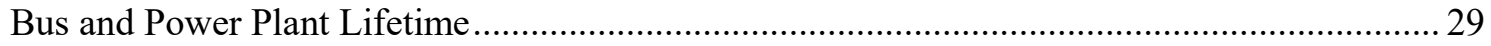

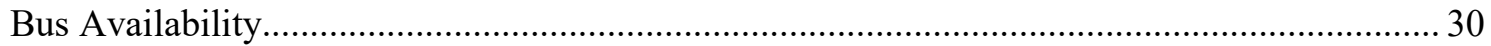

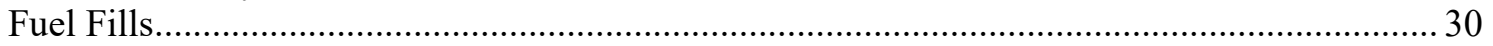

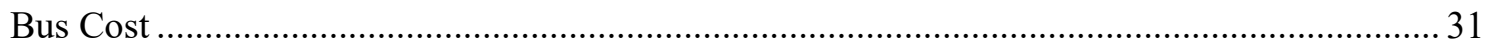

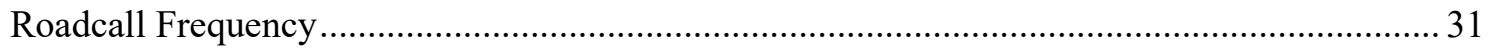

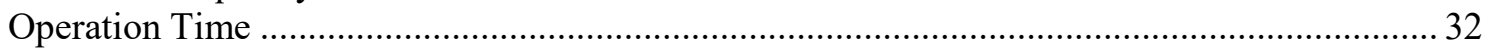

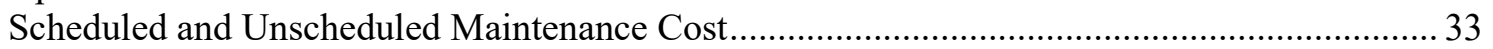

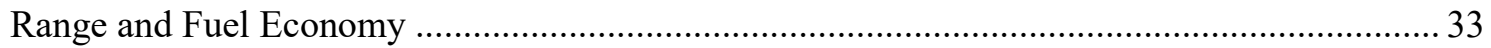

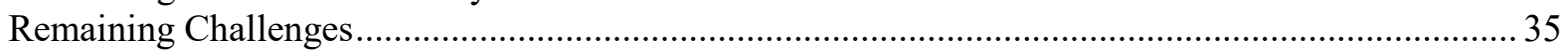

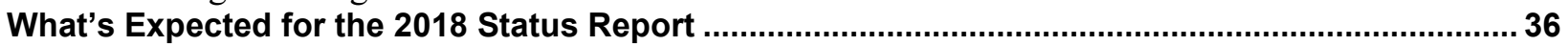

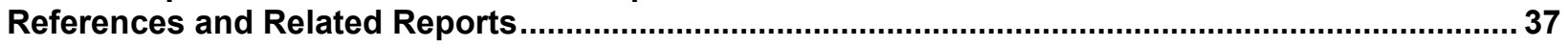

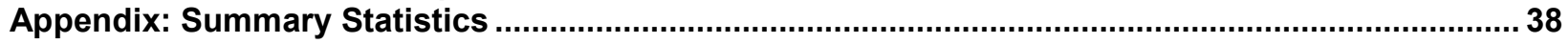

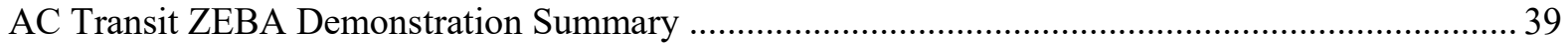

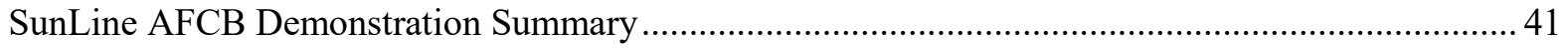

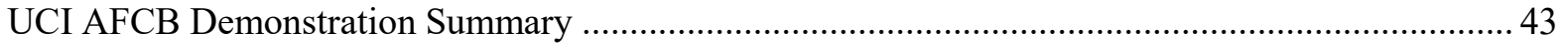

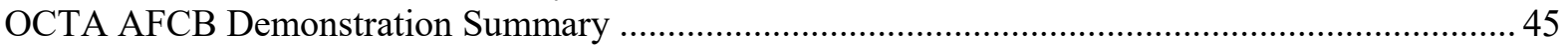

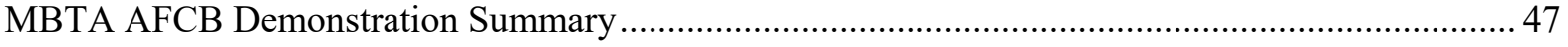




\section{Introduction}

This report is the tenth in a series of annual status reports from the U.S. Department of Energy's (DOE's) National Renewable Energy Laboratory (NREL). It summarizes status and progress from demonstrations of fuel cell transit buses in the United States. Since 2000, NREL has evaluated fuel cell electric bus (FCEB) demonstrations at transit agencies, looking at the buses, infrastructure, and each transit agency's implementation experience. These evaluations have been funded by DOE, the U.S. Department of Transportation's Federal Transit Administration (FTA), and the California Air Resources Board (CARB).

\section{Scope and Purpose}

This annual status report discusses the achievements and challenges of fuel cell propulsion for transit and summarizes the introduction of fuel cell transit buses in the United States. It provides an analysis of the combined results from fuel cell transit bus demonstrations evaluated by NREL with a focus on the most recent data (through July 2017). NREL also publishes detailed reports on individual demonstration results that are posted on the NREL website. ${ }^{2}$

The report's intent is to inform FTA and DOE decision makers who guide future early-stage research and funding; state and local government agencies that fund new propulsion technology transit buses; and interested transit agencies and industry manufacturers.

\section{Organization}

This report is organized into sections as follows.

1. Introduction

2. Fuel Cell Electric Buses in Operation in North America: summarizes existing and upcoming demonstrations in the United States and includes an overview of FTA's National Fuel Cell Bus Program (NFCBP) and other programs that promote cleaner options for transit buses.

3. FCEB Development Process-Technology Readiness Levels: outlines the steps for developing and commercializing FCEBs and indicates where each of the current designs falls in the process.

4. Update of Evaluation Results Through July 2017: presents the results of the most recent NREL evaluations of fuel cell transit bus demonstrations with comparisons for availability, fuel economy, and reliability.

5. Current Status of Fuel Cell Bus Introductions: Summary of Achievements and Challenges: discusses the status and challenges of fuel cell propulsion for transit.

6. What's Expected for the 2018 Report: looks ahead to the results to be presented in next year's assessment report.

7. Appendix: provides summary fuel cell bus data from each of the transit agencies.

\footnotetext{
${ }^{2}$ Website: https://www.nrel.gov/hydrogen/fuel-cell-bus-evaluation.html.
} 


\section{What's New Since the Previous Report}

Table 1 outlines the FCEB designs that were included in the 2016 and 2017 (current) status reports. The 2016 report presented the results from three FCEB demonstration projects featuring fuel-cell-dominant designs. NREL began collecting data on three more projects since the last report. All three projects involve operating an American Fuel Cell Bus (AFCB) ${ }^{3}$ (or multiple AFCBs) in service: one bus at the Massachusetts Bay Transportation Authority (MBTA) in Boston, Massachusetts; one bus at the Orange County Transportation Authority (OCTA) in Orange County, California; and six buses at the Stark Area Regional Transit Authority (SARTA) in Canton, Ohio. NREL has sufficient data on the OCTA bus to include the early analysis results in this report. NREL has a partial data set on the MBTA bus that includes miles, fuel cell hours, and fuel economy. The remaining data on the MBTA bus and from the new evaluation at SARTA will be included in the next status report.

Table 1. Technologies Included in the 2016 or 2017 Status Reports

\begin{tabular}{|l|c|c|c|}
\hline \multicolumn{1}{|c|}{ FCEB Demonstration } & $\begin{array}{c}\text { Included in } \\
\text { 2016 Report }\end{array}$ & $\begin{array}{c}\text { Included in } \\
\text { Current Report }\end{array}$ & $\begin{array}{c}\text { Status } \\
\text { (as of 7/31/17) }\end{array}$ \\
\hline $\begin{array}{l}\text { AC Transit Zero Emission } \\
\text { Bay Area (ZEBA) }\end{array}$ & & & Active \\
\hline SunLine AFCB & & & Active \\
\hline UCI AFCB & & & Active \\
\hline OCTA AFCB & & & Active \\
\hline MBTA AFCB & & & Active \\
\hline
\end{tabular}

Previous status reports have referenced operational cost data from the individual project results reports. For this report, NREL has included an up-to-date analysis of operational costs including scheduled and unscheduled cost and cost per mile by vehicle system. The section also provides historical data on the FCEBs and baseline buses to show cost trends over time.

\footnotetext{
${ }^{3}$ The AFCB design was developed through collaboration between BAE Systems, ElDorado National-California (ENC), and Ballard Power Systems.
} 


\section{Fuel Cell Electric Buses in Operation in the United States}

Table 2 lists current FCEB demonstrations in the United States. These demonstrations continue to focus on identifying improvements to optimize reliability and durability, but are beginning to introduce larger fleets of buses. As of August 2017, 26 FCEBs were in service in demonstrations at several locations throughout the country.

Table 2. Fuel Cell Transit Buses in Active Service in the United States

\begin{tabular}{|c|c|c|c|c|}
\hline & Bus Operator & Location & $\begin{array}{l}\text { Active } \\
\text { Buses }^{b}\end{array}$ & Technology Description \\
\hline 1 & AC Transit, ZEBA ${ }^{a}$ & $\begin{array}{l}\text { San Francisco } \\
\text { Bay Area, CA }\end{array}$ & 13 & $\begin{array}{l}\text { Van Hool bus and hybrid system } \\
\text { integration, US Hybrid support for fuel cell }\end{array}$ \\
\hline 2 & $\begin{array}{l}\text { SunLine Transit Agencya } \\
\text { (AFCB prototype) }\end{array}$ & $\begin{array}{l}\text { Thousand Palms, } \\
\text { CA }\end{array}$ & 1 & $\begin{array}{l}\text { ENC/BAE Systems/Ballard next-generation } \\
\text { advanced design to meet "Buy America" } \\
\text { requirements }\end{array}$ \\
\hline 3 & SunLine Transit Agency ${ }^{c}$ & $\begin{array}{l}\text { Thousand Palms, } \\
\text { CA }\end{array}$ & 3 & $\begin{array}{l}\text { ENC/BAE Systems/Ballard updated AFCB } \\
\text { design }\end{array}$ \\
\hline 4 & $\begin{array}{l}\text { University of California at } \\
\text { Irvine (UCl) }\end{array}$ & Irvine, CA & 1 & AFCB \\
\hline 5 & $\begin{array}{l}\text { Massachusetts Bay } \\
\text { Transportation Authority } \\
(\text { MBTA) }\end{array}$ & Boston, MA & 1 & AFCB \\
\hline 6 & $\begin{array}{l}\text { Orange County } \\
\text { Transportation Authority } \\
(\text { (OCTA) }\end{array}$ & Santa Ana, CA & 1 & AFCB \\
\hline 7 & $\begin{array}{l}\text { Stark Area Regional } \\
\text { Transit Authority } \\
\text { (SARTA)a }\end{array}$ & Canton, $\mathrm{OH}$ & 5 & $\begin{array}{l}\text { AFCB, one bus operated by Ohio State } \\
\text { University for a year }\end{array}$ \\
\hline \multirow[t]{2}{*}{8} & $\begin{array}{l}\text { Flint Mass Transportation } \\
\text { Authorityc }\end{array}$ & Flint, MI & 1 & AFCB \\
\hline & & Total & 26 & \\
\hline
\end{tabular}

a Project received funding through the NFCBP

b Total buses in service as of August 2017

${ }^{c}$ Project received funding through TIGGER

NREL is working with the first seven demonstrations shown in Table 2. During the last year, NREL collected data on the FCEBs demonstrated in projects 1 through 6 . The section "Update of Evaluation Results Through July 2017" provides the most recent results for these six demonstration projects.

\section{New Fuel Cell Buses Under Development}

The FTA has funded several programs that developed zero-emission buses for demonstrations in transit agencies.

- NFCBP: a \$180 million, multiyear, cost-shared research program for developing and demonstrating commercially viable fuel cell technology for transit buses. 
- Transit Investments for Greenhouse Gas and Energy Reduction (TIGGER): \$225 million for capital investments that would reduce greenhouse gas emissions and/or lower the energy use of public transportation systems.

- Low or No Emission Vehicle Deployment Program (Low-No Program): \$186.9 million in funding (FY13-FY17) to transit agencies for capital purchases of zero-emission and low-emission transit buses that have been largely proven in testing and demonstration efforts but are not yet widely deployed.

The NFCBP is a multiyear, cost-shared research program established by FTA in 2006, with an overall goal of developing and demonstrating commercially viable fuel cell technology for transit buses. Additional funding was added to the program over the following 4 years. Projects were competitively selected and included fuel cell bus demonstrations, component development projects, and outreach projects. Three nonprofit consortia-CALSTART (Pasadena, California), the Center for Transportation and the Environment (Atlanta, Georgia), and the Northeast Advanced Vehicle Consortium (Boston, Massachusetts) - are responsible for managing the projects. NREL was funded as a third-party evaluator to assess the viability of the buses demonstrated under the program.

Beyond the NFCBP, FTA has funded fuel cell bus research at several universities and transit agencies around the country. The TIGGER program funded a number of zero-emission buses at transit agencies in the United States. The majority of those buses are battery-electric buses (BEBs); however, SunLine and Flint MTA received funding for FCEBs. These TIGGER projects, listed in Table 2, include an upgraded AFCB design based on lessons learned from the first bus demonstrated at SunLine.

FTA's newest program is the Low-No Program. This program provides funding for capital acquisitions or leases of zero-emission and low-emission transit buses, including BEBs and FCEBs. The primary purpose is to deploy the cleanest U.S.-made transit buses that have been proven in testing and demonstrations but are not yet widely deployed in transit fleets. Since the inception of the program, 88 projects were awarded nearly $\$ 187$ million in funding to add lowor zero-emission buses to transit fleets across the United States. At least 234 buses will be deployed through the program including FCEBs, BEBs, and hybrid electric buses. The FCEB projects include 17 FCEBs; five AFCBs will be deployed at SunLine, ten AFCBs will be deployed at SARTA in Canton, Ohio, and two New Flyer FCEBs will be deployed at Champaign-Urbana Mass Transit District in Illinois.

The state of California funds technology development and demonstration programs that include FCEB projects. Both the California Energy Commission (CEC) and CARB have funded demonstrations of FCEBs. One of the more recent programs is CARB's Zero-Emission Truck and Bus Pilot Commercial Deployment Projects. Two FCEB-related projects have been approved for funding. Table 3 lists the new demonstration projects from all funding sources that are expected to field as many as 42 more fuel cell buses over the next few years. 
Table 3. New Fuel Cell Transit Buses Planned in the United States

\begin{tabular}{|c|c|c|c|c|c|}
\hline $\begin{array}{c}\text { Bus } \\
\text { Operator }\end{array}$ & Program & Location & $\begin{array}{l}\text { Number } \\
\text { of Buses }\end{array}$ & Technology Description & $\begin{array}{l}\text { Actual/Estimated } \\
\text { Service Start }\end{array}$ \\
\hline $\begin{array}{l}\text { AC Transit } \\
\text { (CALSTART) }\end{array}$ & NFCBP & $\begin{array}{l}\text { Oakland, } \\
\text { CA }\end{array}$ & 1 & $\begin{array}{l}\text { New Flyer } 60 \text {-ft bus with next- } \\
\text { generation Ballard fuel cell, } \\
\text { Siemens hybrid propulsion } \\
\text { system }\end{array}$ & $\begin{array}{l}\text { After Altoona } \\
\text { testing ends }\end{array}$ \\
\hline $\begin{array}{l}\text { SunLine } \\
\text { (CALSTART) }\end{array}$ & NFCBP & $\begin{array}{l}\text { Thousand } \\
\text { Palms, CA }\end{array}$ & 1 & $\begin{array}{l}\text { ENC bus with a battery- } \\
\text { dominant fuel cell system from } \\
\text { BAE Systems and a US Hybrid } \\
\text { fuel cell }\end{array}$ & Q4 2017 \\
\hline SunLine & $\begin{array}{l}\text { Low-No } \\
(2015)\end{array}$ & $\begin{array}{l}\text { Thousand } \\
\text { Palms, CA }\end{array}$ & 5 & AFCB & 2018 \\
\hline SARTA & NFCBP & $\begin{array}{l}\text { Canton, } \\
\text { Columbus, } \\
\text { OH }\end{array}$ & 1 & AFCB & $\begin{array}{l}\text { After Altoona } \\
\text { testing ends }\end{array}$ \\
\hline SARTA & $\begin{array}{l}\text { Low-No } \\
(2015)\end{array}$ & $\begin{array}{l}\text { Canton, } \\
\mathrm{OH}\end{array}$ & 1 & AFCB & $\begin{array}{c}4 \text { of } 5 \text { buses } \\
\text { delivered }\end{array}$ \\
\hline SunLine & CEC & $\begin{array}{l}\text { Thousand } \\
\text { Palms, CA }\end{array}$ & 1 & $\begin{array}{l}\text { New Flyer Xcelsior } 40 \text {-ft bus, } \\
\text { Hydrogenics fuel cell }\end{array}$ & Q4 2017 \\
\hline SARTA & $\begin{array}{l}\text { Low-No } \\
(2016 / 17) \\
\end{array}$ & $\begin{array}{l}\text { Canton, } \\
\mathrm{OH}\end{array}$ & 5 & AFCB & TBD \\
\hline $\begin{array}{l}\text { AC Transit, } \\
\text { OCTA }\end{array}$ & CARB & $\begin{array}{l}\text { Oakland, } \\
\text { Santa Ana, } \\
\text { CA }\end{array}$ & 20 & $\begin{array}{l}\text { New Flyer bus with Ballard fuel } \\
\text { cell, } 10 \text { buses for each agency }\end{array}$ & TBD \\
\hline SunLine & CARB & $\begin{array}{l}\text { Thousand } \\
\text { Palms, CA }\end{array}$ & 5 & $\begin{array}{l}\text { New Flyer bus with } \\
\text { Hydrogenics fuel cell }\end{array}$ & Q1 2018 \\
\hline $\begin{array}{l}\text { Champaign- } \\
\text { Urbana Mass } \\
\text { Transit } \\
\text { District } \\
\end{array}$ & $\begin{array}{c}\text { Low-No } \\
(2017)\end{array}$ & $\begin{array}{l}\text { Champaign } \\
\text {-Urbana, IL }\end{array}$ & 2 & New Flyer 60-ft & TBD \\
\hline \multicolumn{3}{|c|}{ Total } & 42 & & \\
\hline
\end{tabular}

\section{Fuel Cell Bus Demonstrations Outside North America}

Many countries worldwide are investing in fuel cell bus technology and are funding demonstration projects to commercialize the technology. The European Union is pushing emissions reductions and has set aggressive goals. Meeting its carbon neutral and zero-emission goals requires zero-emission vehicles, so the European Union is funding a number of projects that demonstrate FCEBs in cities around Europe. Toyota has announced production of FCEBs in Japan. The Korean Ministry of Environment developed a roadmap for deploying fuel cell electric vehicles, including buses, in the country. China has also announced plans for large numbers of FCEB and BEBs to address emissions concerns. Knowledge of the major demonstrations outside North America facilitates our understanding of how the technology is progressing worldwide. Although this report focuses on U.S. projects, several international demonstrations are of interest.

CHIC: The Clean Hydrogen in European Cities (CHIC) project was a public-private partnership supported through funding from the Fuel Cell and Hydrogen Joint Undertaking (FCH JU). CHIC 
built upon the experience of previous FCEB demonstration projects, bringing together a coalition of partners from industry, cities, and research organizations to operate 54 FCEBs and four hydrogen-powered internal combustion engine buses in nine cities in Europe and Canada. The buses were built by five different original equipment manufacturers (OEMs) with fuel cell systems from two suppliers. The project was completed in December 2016 and the final report outlining the results was published in February $2017 .^{4}$ The project partners report that the FCEBs met or exceeded expectations, operating for more than 519,000 hours and accumulating $9,600,000 \mathrm{~km}$ (more than 5,965,000 miles). The average fuel economy for the full-size FCEBs $(12 \mathrm{~m}$ or $40 \mathrm{ft})$ was less than $10 \mathrm{~kg} / 100 \mathrm{~km}$ (7.02 miles per diesel gallon equivalent). Availability averaged $69 \%$, although two cities exceeded the goal of $85 \%$.

High V.LO-City: The High V.LO-City project, also supported by the FCH JU, has a goal of accelerating the market for new-generation FCEBs. ${ }^{5}$ The project, which began in 2012, plans to field 14 FCEBs in four regions across the European Union. Project goals include demonstrating lower fuel use, increased availability, and reduced maintenance cost. The project ends in 2019.

HyTransit: Another FCH JU-supported project, HyTransit, will introduce six FCEBs and hydrogen infrastructure in Aberdeen, Scotland. ${ }^{6}$ The project began in 2013 and will run through 2018. The six buses will operate alongside the four FCEBs that are part of the High V.LO-City project. The buses went into service in March 2015.

3Emotion: The FCH JU is also providing funding for the Environmentally friendly Efficient Electric Motion (3Emotion) project. ${ }^{7}$ This project aims to bridge the gap between current demonstrations and larger deployments by demonstrating FCEBs and developing a plan for commercialization. 3Emotion will deploy 21 FCEBs at six sites around Europe.

JIVE: A new project supported by the FCH JU, the Joint Initiative for hydrogen Vehicles across Europe (JIVE) will deploy 142 FCEBs in nine locations in Europe. ${ }^{8}$ The project has a goal of addressing issues such as cost of ownership and increasing availability. The bus procurement will be coordinated between locations to increase production volume and lower capital cost. JIVE will also test hydrogen infrastructure designed to service fleets of more than 20 FCEBs.

Toyota: In October 2016, Toyota announced plans to introduce 100 FCEBs in Japan prior to the Tokyo 2020 Olympic and Paralympic Games. ${ }^{9}$ Toyota, with its subsidiary Hino, has been testing its FCEB for a number of years. The next-generation technology for the FCEB is based on Toyota's light-duty fuel cell vehicle, the Mirai, and uses 10 hydrogen storage cylinders at 10,000 psi. (U.S.-based FCEBs have 5,000 psi hydrogen storage systems.)

Korea: Hyundai has been developing fuel cell technology for buses for the last 10 years. The current pre-commercial product in testing is their third-generation design. Hyundai plans to begin production of its commercial product in 2020. In 2015, the Korean government's Ministry

\footnotetext{
${ }^{4}$ CHIC-Final Publishable Summary Report: http://chic-project.eu/

${ }^{5}$ Project website: http://highvlocity.eu

${ }^{6}$ Project website: http://aberdeeninvestlivevisit.co.uk/H2-Aberdeen/Hydrogen-Bus/Hydrogen-Bus-Project.aspx

${ }^{7}$ Project website: http://www.3emotion.eu/

${ }^{8}$ Project website: $\underline{\text { http://www.fch.europa.eu/project/joint-initiative-hydrogen-vehicles-across-europe }}$

9 Toyota press release: http://newsroom.toyota.co.jp/en/detail/13965745/
} 
of Environment developed a roadmap for deploying hydrogen-fueled vehicles. The initial plan would replace as many as 2,000 compressed natural gas (CNG) buses each year with FCEBs. ${ }^{10}$

China: China's New Energy Vehicle Technology Roadmap calls for the deployment of fuel cell and electric vehicles including buses. Ballard announced an agreement in 2015 to produce fuel cell components for as many as 300 FCEBs in China. ${ }^{11}$

\footnotetext{
${ }^{10}$ Presentation at the $10^{\text {th }}$ FCB Workshop in London, November 2016: http://www.cte.tv/wpcontent/uploads/2016/12/4 Jeon-pdf-image-150x150.jpg

${ }^{11}$ Ballard press release: $\underline{\text { http://www.ballard.com/about-ballard/newsroom/news-releases/2015/09/25/ballard-lands- }}$ $\$ 17 \mathrm{~m}$-deal-for-deployment-of-300-fuel-cell-buses-in-china
} 


\section{FCEB Development Process-Technology Readiness Levels}

In the 2012 status report, NREL introduced a guideline for assessing the technology readiness level (TRL) for FCEBs. This guideline was developed using a Technology Readiness Assessment Guide ${ }^{12}$ published by DOE in September 2011. NREL presented a TRL guide tailored for the commercialization of FCEBs. The guideline considers the FCEB as a whole and does not account for differing TRLs for separate components or subsystems. Some subsystems may include off-the-shelf components that are considered commercial, while other subsystems may feature newly designed components at an earlier TRL. Figure 1 provides a graphic representation of this process. A table outlining the TRLs and definitions is included in the Appendix.

\section{Commercialization Process}

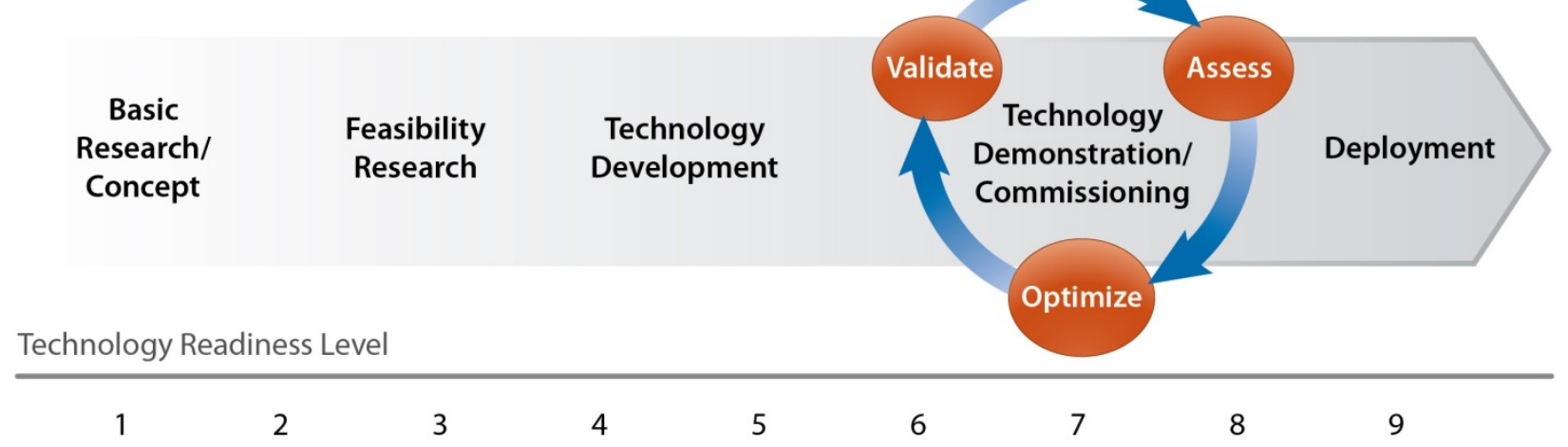

Figure 1. Graphic representation of the commercialization process developed for FCEBs

FCEB development is currently in the technology demonstration/commissioning phase that includes TRLs 6 through 8. This phase begins the process of validating the design, analyzing the results, and reconfiguring or optimizing the design as needed. At this point in development, capital and operating costs for FCEBs are still much higher than those of conventional diesel technology. This is to be expected, considering diesel is a very mature technology (TRL 9) and FCEBs are still in the development stage.

Over the last year, NREL collected data on two different FCEB designs - the Van Hool FCEB and the AFCB built by ENC - at five demonstration sites. Van Hool is a Belgium-based OEM and the buses operated by AC Transit do not meet FTA's "Buy America" requirements. While Van Hool is moving forward with a next-generation FCEB design in Europe, transit agencies in the United States are not likely to purchase those buses because of the FTA requirements. The ENC buses are built in the United States and meet "Buy America" requirements. The development team of BAE Systems, Ballard, and ENC handled AFCB procurements in the early stage. Over the last year, the procurement process for AFCBs has moved toward the standard practice of the bus OEM taking the lead role for bus builds, and ENC is building AFCBs on its manufacturing line along with other technologies. An AFCB is currently in testing at the Altoona Bus Research and Testing Center, which is a requirement for transit agencies that use FTA

${ }^{12}$ DOE Technology Readiness Assessment Guide, G 143.3-4a, available at http://www2.lbl.gov/DIR/assets/docs/TRL\%20guide.pdf. 
funds. These are major steps toward commercialization of FCEBs. When accounting for planned procurements, there will be at least $25 \mathrm{AFCBs}$ in service within the next few years. NREL considers this design to be in the early TRL 8 stage.

Over the next year, New Flyer will field a 40-foot FCEB design based on its current Xcelsior platform. New Flyer currently has a 60 -foot version of its FCEB design in testing at Altoona. This new FCEB design will increase the choices for transit agencies interested in adopting the technology. The larger orders for FCEBs are expected to contribute to further cost reductions. 


\section{Update of Evaluation Results Through July 2017}

The data presented in this section represent the most recent results that have not been presented in a previous annual status report. These data come from five different FCEB demonstrations. To simplify the presentation of the data, each FCEB is assigned an identifier that includes a site abbreviation followed by a manufacturer or project designation. Both FCEB designs presented in this report have hybrid systems. Table 4 provides some specifications for each FCEB design. Table 5 outlines the number of buses at each site and provides the unique identifier used in the tables and figures in the following sections. The buses at UCI, OCTA, and MBTA are the same configuration as the buses at SunLine. Figure 2 shows a picture of one of the Van Hool FCEBs at AC Transit. Figure 3 shows the AFCBs operated at SunLine, UCI, OCTA, and MBTA.

Table 4. Selected FCEB Specifications

\begin{tabular}{|l|c|c|}
\hline & Van Hool FCEB & AFCB \\
\hline Bus OEM & Van Hool & ENC \\
\hline Model & A300L & Axcess \\
\hline Bus length & $40 \mathrm{ft}$ & $40 \mathrm{ft}$ \\
\hline Gross vehicle weight & $39,350 \mathrm{lb}$ & $43,420 \mathrm{lb}$ \\
\hline Fuel cell OEM & UTC Power & Ballard \\
\hline Fuel cell model & Puremotion 120 & FCvelocity HD6 \\
\hline Fuel cell power (kW) & 120 net power & 150 gross power \\
\hline Hybrid system integrator & Van Hool & BAE Systems \\
\hline Design strategy & Fuel cell dominant & Fuel cell dominant \\
\hline Energy storage OEM & EnerDel & A123 \\
\hline Energy storage type & Li-ion & Li-ion \\
\hline Energy storage capacity & $21 \mathrm{kWh}$ & $11 \mathrm{kWh}$ \\
\hline Hydrogen storage pressure $(\mathrm{psi})$ & 5,000 & 5,000 \\
\hline Hydrogen cylinders & 8 & 8 \\
\hline Hydrogen capacity $(\mathrm{kg})$ & 40 & 50 \\
\hline
\end{tabular}

Table 5. FCEB Identifiers and Numbers by Site

\begin{tabular}{|l|l|c|c|c|}
\hline \multicolumn{1}{|c|}{ Identifier } & \multicolumn{1}{|c|}{ Transit Agency } & Design & $\begin{array}{c}\text { Number } \\
\text { of Buses }\end{array}$ & Model Year \\
\hline ACT ZEBA & AC Transit & Van Hool & 13 & 2010 \\
\hline SL AFCB & SunLine & AFCB & 4 & 2011,2014 \\
\hline UCI AFCB & Anteater Express, UCl & AFCB & 1 & 2015 \\
\hline OCTA AFCB & OCTA & AFCB & 1 & 2016 \\
\hline MBTA AFCB & MBTA & AFCB & 1 & 2015 \\
\hline
\end{tabular}




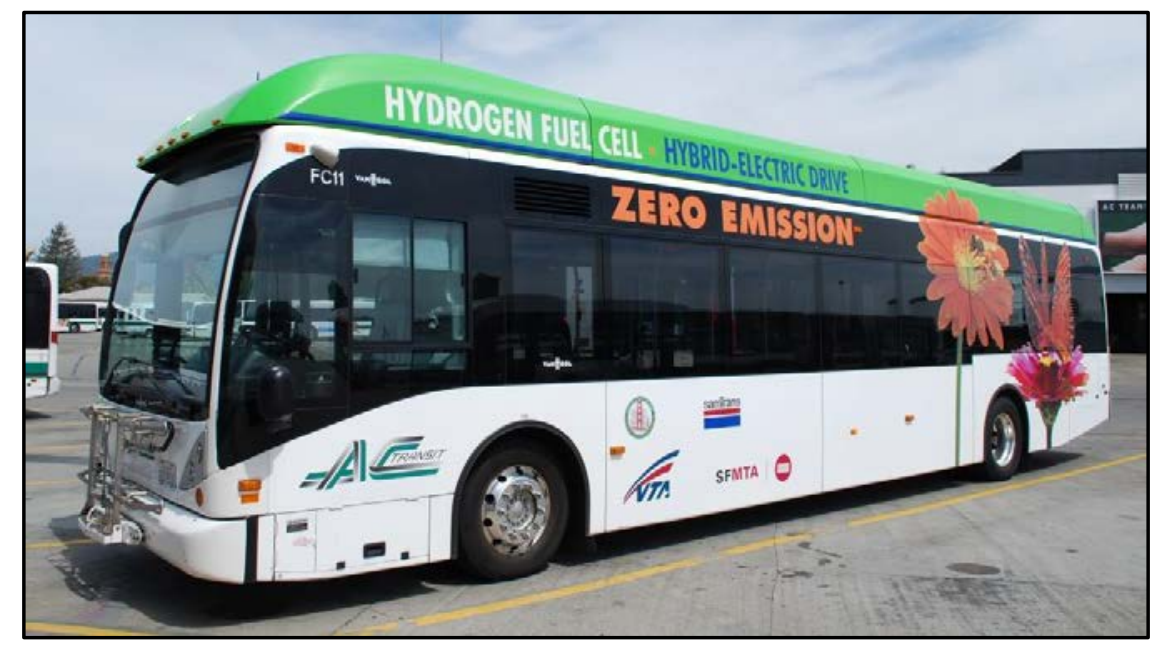

Figure 2. Van Hool FCEB at AC Transit

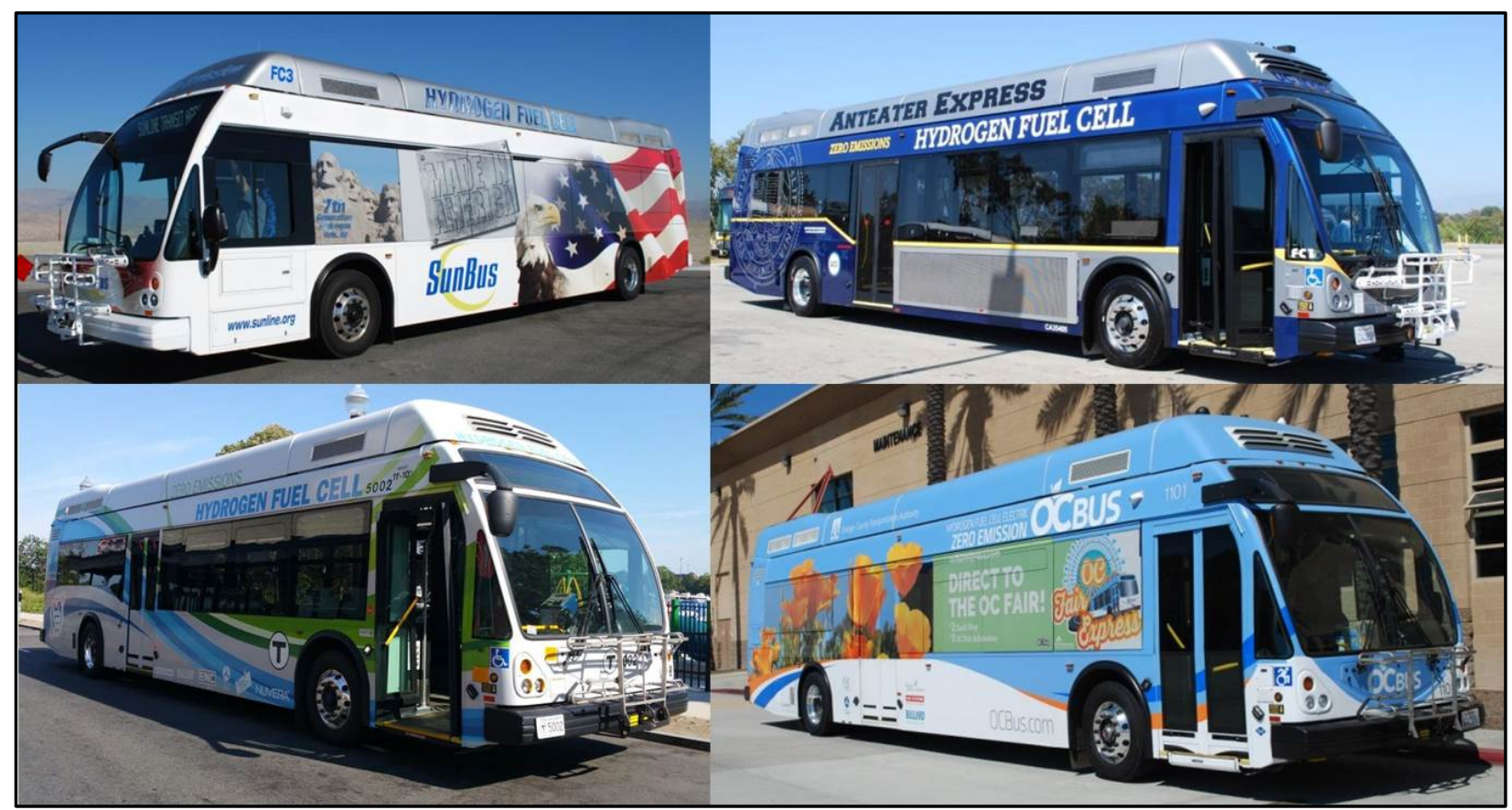

Figure 3. AFCBs at SunLine (top left), UCI (top right), MBTA (lower left), and OCTA (lower right)

\section{Baseline Buses}

Conventional baseline bus data are provided for comparison with FCEB data when comparable buses are available. Data on baseline buses are being collected for four of the five demonstrations. For AC Transit and MBTA, the primary comparison is with diesel buses. As of this report, the data set for the MBTA baseline buses is incomplete and not included in the analysis. The baseline buses at SunLine and OCTA are CNG buses. UCI has a small fleet of diesel buses; however, those buses are much older and are not similar in size and weight, so no baseline buses are included in the analysis. All baseline buses are commercial products at TRL 9. 
Table 6. Selected Specifications for the Baseline Buses

\begin{tabular}{|l|c|c|c|}
\hline & Diesel & CNG & CNG \\
\hline Transit agency & AC Transit & SunLine & OCTA \\
\hline Number of buses & 10 & 5 & 10 \\
\hline Bus OEM & Gillig & New Flyer & New Flyer \\
\hline Model year & 2013 & 2016 & 2016 \\
\hline Bus length & $40 \mathrm{ft}$ & $40 \mathrm{ft}$ & $40 \mathrm{ft}$ \\
\hline Gross vehicle weight & $39,600 \mathrm{lb}$ & $44,004 \mathrm{lb}$ & $42,290 \mathrm{lb}$ \\
\hline Engine & Cummins ISL, 8.9L & Cummins ISL G, 8.9L & Cummins ISL G, 8.9L \\
\hline Rated power & $280 \mathrm{hp} \mathrm{@} \mathrm{2,200} \mathrm{rpm}$ & $280 \mathrm{hp} \mathrm{@} \mathrm{2,200} \mathrm{rpm}$ & $280 \mathrm{hp} \mathrm{@} \mathrm{2,200} \mathrm{rpm}$ \\
\hline Emissions equipment & $\begin{array}{c}\text { Diesel particulate } \\
\text { filter and selective } \\
\text { catalytic reduction }\end{array}$ & 3-way catalyst & 3-way catalyst \\
\hline TRL & 9 & 9 & 9 \\
\hline
\end{tabular}

The Appendix summarizes the results by demonstration location and provides additional charts that detail some of the results by agency.

Data periods included in the report-The report focuses on data from August 2016 through July 2017. The MBTA bus data begin in November 2016 with the first full month for the analysis being December 2016. NREL has an incomplete data set for the project, so the data reported for MBTA only include miles, hours, and fuel economy for the AFCB.

\section{Total Miles and Hours}

Table 7 shows miles, hours, and average speed for each FCEB fleet. The AFCBs at SunLine and OCTA have the higher average speeds at 12.3 and 13.4 miles per hour ( $\mathrm{mph}$ ) respectively. The ZEBA buses in service at AC Transit and the AFCBs at UCI and MBTA tend to operate at lower average speeds of $8.8,9.7$, and $10.4 \mathrm{mph}$ respectively.

Table 7. Annual Miles and Hours for the FCEBs

\begin{tabular}{|l|c|c|c|c|c|c|}
\hline \multicolumn{1}{|c|}{ ID } & Period & Months & $\begin{array}{c}\text { No. of } \\
\text { Buses }\end{array}$ & Miles & Hours & $\begin{array}{c}\text { Avg. Speed } \\
(\mathrm{mph})\end{array}$ \\
\hline ACT ZEBA & $8 / 16-7 / 17$ & 12 & 13 & 451,533 & 51,294 & 8.8 \\
\hline SL AFCB & $8 / 16-7 / 17$ & 12 & 4 & 105,826 & 8,601 & 12.3 \\
\hline UCI AFCB & $8 / 16-7 / 17$ & 12 & 1 & 25,422 & 2,626 & 9.7 \\
\hline OCTA AFCB & $8 / 16-7 / 17$ & 12 & 1 & 12,008 & 894 & 13.4 \\
\hline MBTA AFCB & $12 / 16-7 / 17$ & 8 & 1 & 4,804 & 579 & 10.4 \\
\hline Overall FCEB & & & 20 & 599,593 & 63,949 & 9.4 \\
\hline
\end{tabular}

\section{Bus Use}

Table 8 shows the average monthly bus use for the FCEBs and the respective baseline buses. The target of 3,000 miles has not been achieved by any of the fleets. Despite the target not being met fleet wide, 7 of the 13 individual AC Transit buses have averaged more than 3,000 miles per month in the last data period. All transit agencies have been operating their FCEBs for fewer miles than they operate their baseline buses. AC Transit has increased service for the buses $8 \%$ in monthly miles from the last reporting period. Despite the increase in usage by AC Transit, the average monthly miles for all FCEBs combined has decreased slightly from the last reporting 
period. This decrease is largely due to the addition of the buses at OCTA and MBTA, which have low usage.

Table 8. Monthly Miles

\begin{tabular}{|l|c|c|c|c|c|c|c|c|c|}
\hline \multicolumn{1}{|c|}{ ID } & \multicolumn{4}{|c|}{ FCEB Miles } & \multicolumn{4}{c|}{ Baseline Bus Miles } \\
\hline Period & Months & $\begin{array}{c}\text { No. of } \\
\text { Buses }\end{array}$ & $\begin{array}{c}\text { Total } \\
\text { Miles }\end{array}$ & $\begin{array}{c}\text { Avg. } \\
\text { Monthly } \\
\text { Miles }\end{array}$ & Months & $\begin{array}{c}\text { No. of } \\
\text { Buses }\end{array}$ & $\begin{array}{c}\text { Total } \\
\text { Miles }\end{array}$ & $\begin{array}{c}\text { Avg. } \\
\text { Monthly } \\
\text { Miles }\end{array}$ \\
\hline SL & $8 / 16-7 / 17$ & 12 & 13 & 451,533 & 2,894 & 12 & 10 & 473,199 & 3,943 \\
\hline UCI & $8 / 16-7 / 17$ & 12 & 4 & 105,826 & 2,205 & 12 & 5 & 319,013 & 5,317 \\
\hline OCTA & $8 / 16-7 / 17$ & 12 & 1 & 25,422 & 2,119 & - & - & - & - \\
\hline MBTA & $12 / 16-7 / 17$ & 12 & 1 & 12,008 & 1,001 & 12 & 10 & 384,274 & 3,202 \\
\hline Overall & & 8 & 1 & 4,804 & 601 & n/a & n/a & n/a & n/a \\
\hline
\end{tabular}

\section{Availability}

Availability for all of NREL's evaluations is calculated as the percentage of days the buses are actually available out of days that buses are planned for operation. Planned service days for these evaluations vary depending on the transit agency. Some agencies have planned service every day while others plan for weekdays only with some weekend service. For agencies with planned weekday service, weekends are included in the calculation only if the bus operated in service on those days. If a bus is not scheduled to operate on the weekend or on a holiday, it is not counted as unavailable. Table 9 summarizes the availability of the FCEBs at each transit agency and the baseline buses. The overall availability for the FCEBs as a group is $76 \%{ }^{13}$

At AC Transit, the buses are planned to operate every day of the week excluding holidays. Availability for the AC Transit ZEBA FCEBs was $80 \%$ for the entire data period, which is an improvement from what was reported in the 2016 report (77\%). Individual availability for the 13 buses ranged from a low of $50 \%$ to a high of $95 \%$.

At SunLine, the buses are typically planned to operate on weekdays; however, they often operate on weekends as well. SunLine had a decrease in availability from $77 \%$ last reporting period to $73 \%$ this period. Individual availability for the four buses ranged between $59 \%$ and $82 \%$ for the data period. The primary issue affecting availability was attributed to the hybrid propulsion system of one of the buses.

The UCI AFCB is operated on campus circulator routes and is planned for weekday service when the university is in session. The UCI AFCB has an average availability of $90 \%$ during the data period. The monthly availability of the bus has ranged from $25 \%$ to $100 \%$.

The OCTA buses are expected to operate every day. The OCTA AFCB had the lowest availability of the group. This was a result of a combination of factors including maintenance issues that were difficult to identify and availability of resources for diagnosing the trouble.

\footnotetext{
${ }^{13}$ This calculation is based on combining the group of buses as one fleet; therefore the high and low availability of the single buses at UCI and OCTA do not have a significant impact on the overall availability.
} 
The MBTA bus is expected to operate every day; however, NREL has not received availability data as of this report.

Table 9. Availability for the FCEBs

\begin{tabular}{|l|c|c|c|c|c|c|}
\hline \multicolumn{1}{|c|}{ ID } & Period & Months & $\begin{array}{c}\text { No. of } \\
\text { Buses }\end{array}$ & $\begin{array}{c}\text { Planned } \\
\text { Days }\end{array}$ & $\begin{array}{c}\text { Days } \\
\text { Available }\end{array}$ & $\begin{array}{c}\text { Percent } \\
\text { Available }\end{array}$ \\
\hline ACT ZEBA & $8 / 16-7 / 17$ & 12 & 13 & 4,745 & 3,777 & $80 \%$ \\
\hline SL AFCB & $8 / 16-7 / 17$ & 12 & 4 & 1,165 & 847 & $73 \%$ \\
\hline UCI AFCB & $8 / 16-7 / 17$ & 12 & 1 & 251 & 226 & $90 \%$ \\
\hline OCTA AFCB & $8 / 16-7 / 17$ & 12 & 1 & 365 & 130 & $36 \%$ \\
\hline Overall FCEB & & & 19 & 6,526 & 4,980 & $76 \%$ \\
\hline Diesel & $8 / 16-7 / 17$ & 12 & 10 & 3,650 & 3,335 & $91 \%$ \\
\hline CNG & $8 / 16-7 / 17$ & 12 & 5 & 1,624 & 1,440 & $89 \%$ \\
\hline
\end{tabular}

Figure 4 tracks the overall monthly availability for the FCEBs and baseline buses. The overall average availability for the FCEBs as a group is shown in dark green. The overall availability of the fuel cell system is also included on the chart as a light green line. The fuel cell system availability was above the DOE/FTA ultimate target of $90 \%$ for most of the reporting period.

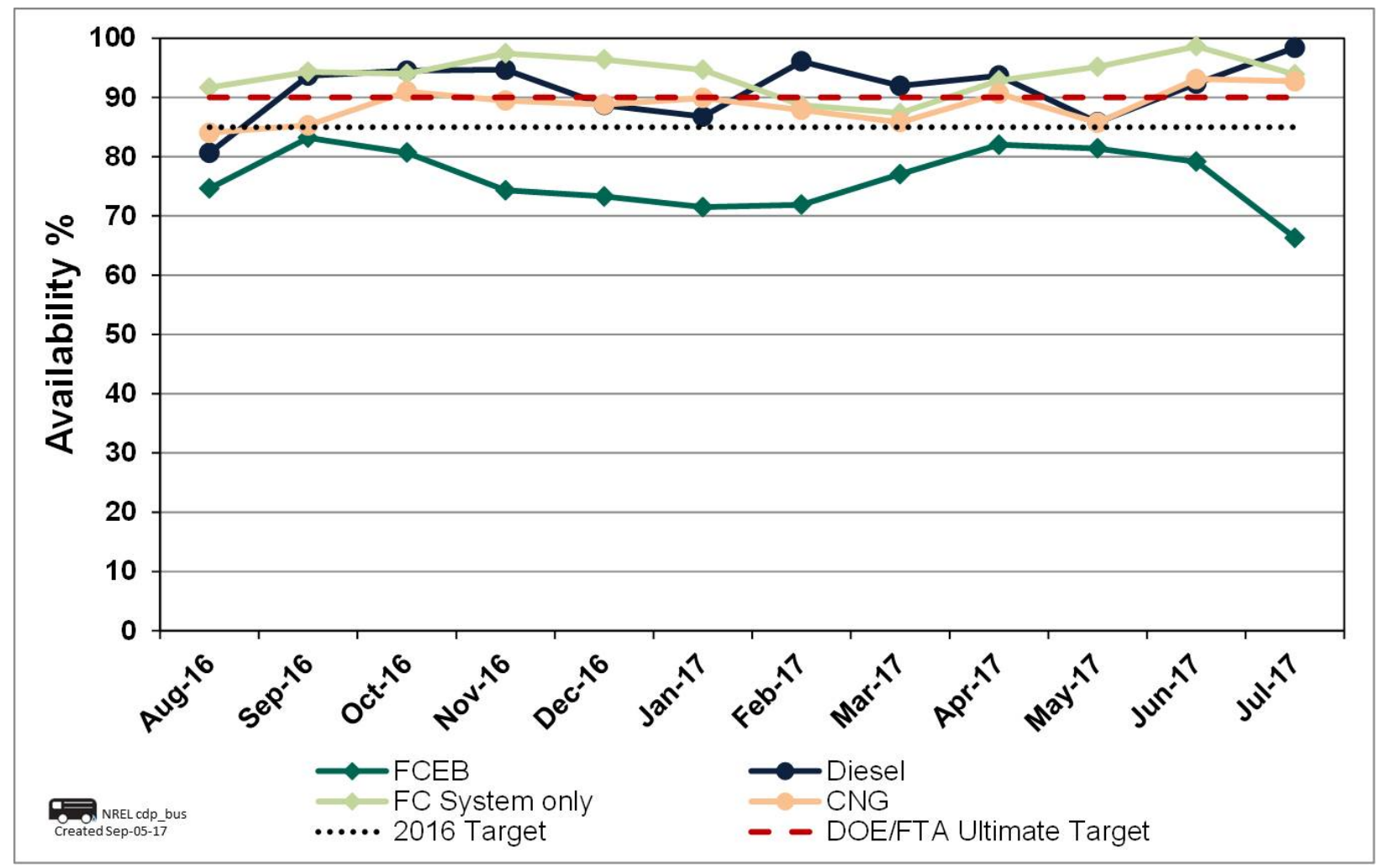

Figure 4. Monthly availability for the FCEBs

Figure 5 presents individual pie charts that show the overall availability for the data period and separates the reasons for unavailability by category for each of the demonstrations. The data provided for four demonstrations included the specific reason for each day a bus was not available. The FC system category includes the fuel cell module and balance of plant components. The hybrid propulsion category includes electric drive components not including the battery pack. For the AFCB, the hybrid system cooling is also included in this category 
although the bus OEM supplies this system. Many of the unavailability days categorized as hybrid propulsion were due to issues with this system. This categorization is based on the diagnostic information at that time. Occasionally, an issue proves challenging to troubleshoot and the cause is eventually traced to a system other than that of the original diagnosis. For these cases, NREL changes the unavailability reason retroactively to reflect the updated information.

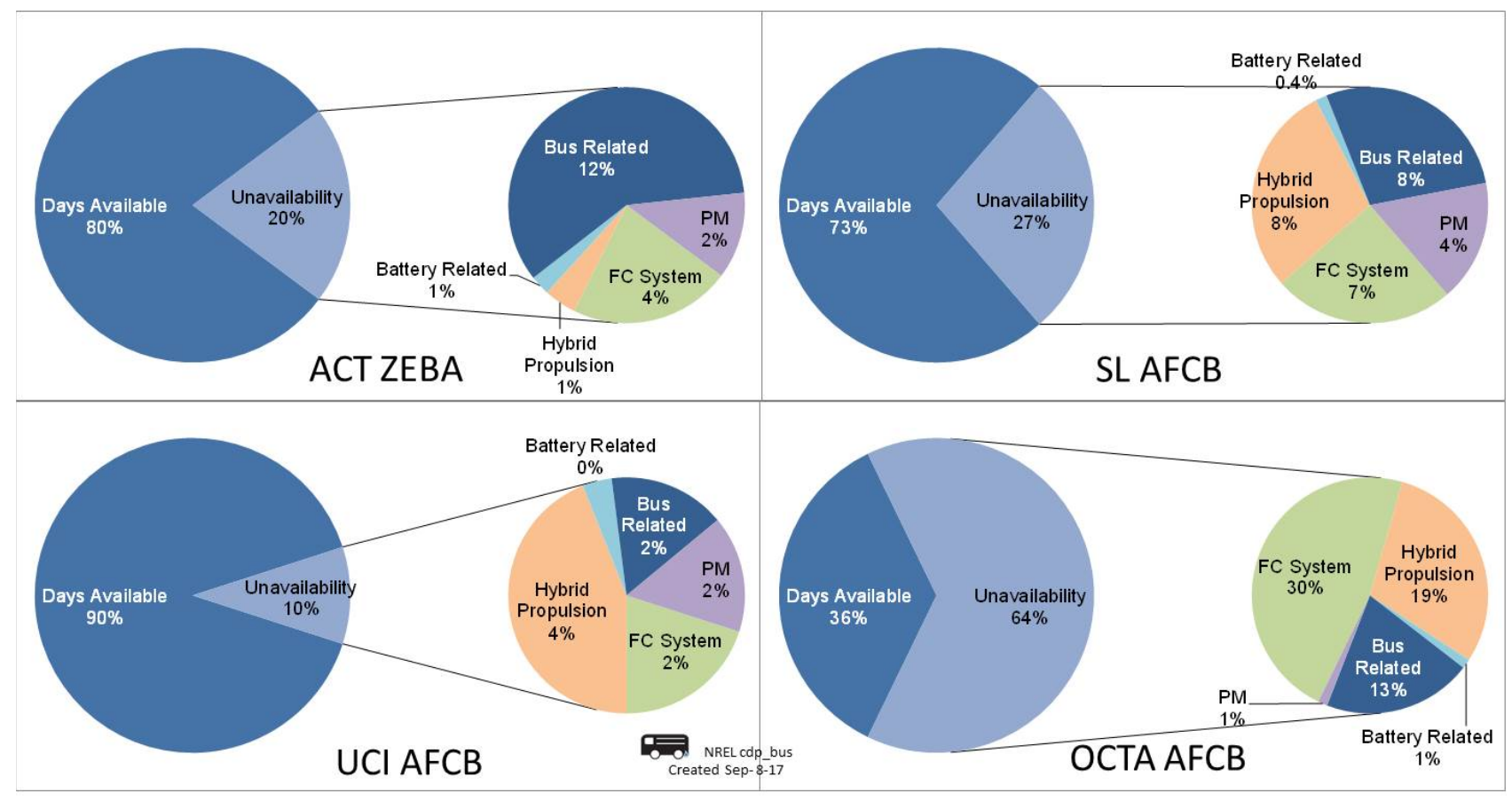

Figure 5. Reasons for unavailability for the FCEBs

\section{Fuel Economy}

Table 10 shows the average in-use fuel economy in miles per diesel gallon equivalent (dge) for each type of FCEB compared to the conventional baseline bus technology at the same site, if available. The fuel economy for the ZEBA buses is 1.4 times higher than that of the Gillig diesel buses. The AFCBs at SunLine show improved fuel economy that is 1.7 times higher than that of the CNG baseline buses. As mentioned previously, the UCI AFCB has no similar baseline buses for comparison. The OCTA AFCB fuel economy is almost twice that of the CNG baseline buses. As of this report, the data set for the MBTA baseline diesel buses is incomplete. 
Table 10. Average Fuel Economy Comparisons Between the FCEBs and Baseline Buses

\begin{tabular}{|l|c|c|c|}
\hline \multicolumn{1}{|c|}{ ID } & $\begin{array}{c}\text { Miles per kg or } \\
\mathrm{gge}^{\mathrm{a}}\end{array}$ & Miles per dge & $\begin{array}{c}\text { Difference Compared } \\
\text { To Baseline }\end{array}$ \\
\hline ACT ZEBA & 5.07 & 5.73 & $1.4 \mathrm{x}$ \\
\hline ACT Gillig diesel & - & 4.23 & - \\
\hline SL AFCB & 5.32 & 6.02 & $1.7 \mathrm{x}$ \\
\hline SL CNG & 3.23 & 3.61 & - \\
\hline UCI AFCB & 5.15 & 5.82 & - \\
\hline OCTA AFCB & 6.71 & 7.59 & $1.9 \mathrm{x}$ \\
\hline OCTA CNG & 3.62 & 4.05 & - \\
\hline MBTA AFCB & 4.30 & 4.86 & - \\
\hline
\end{tabular}

a gasoline gallon equivalent

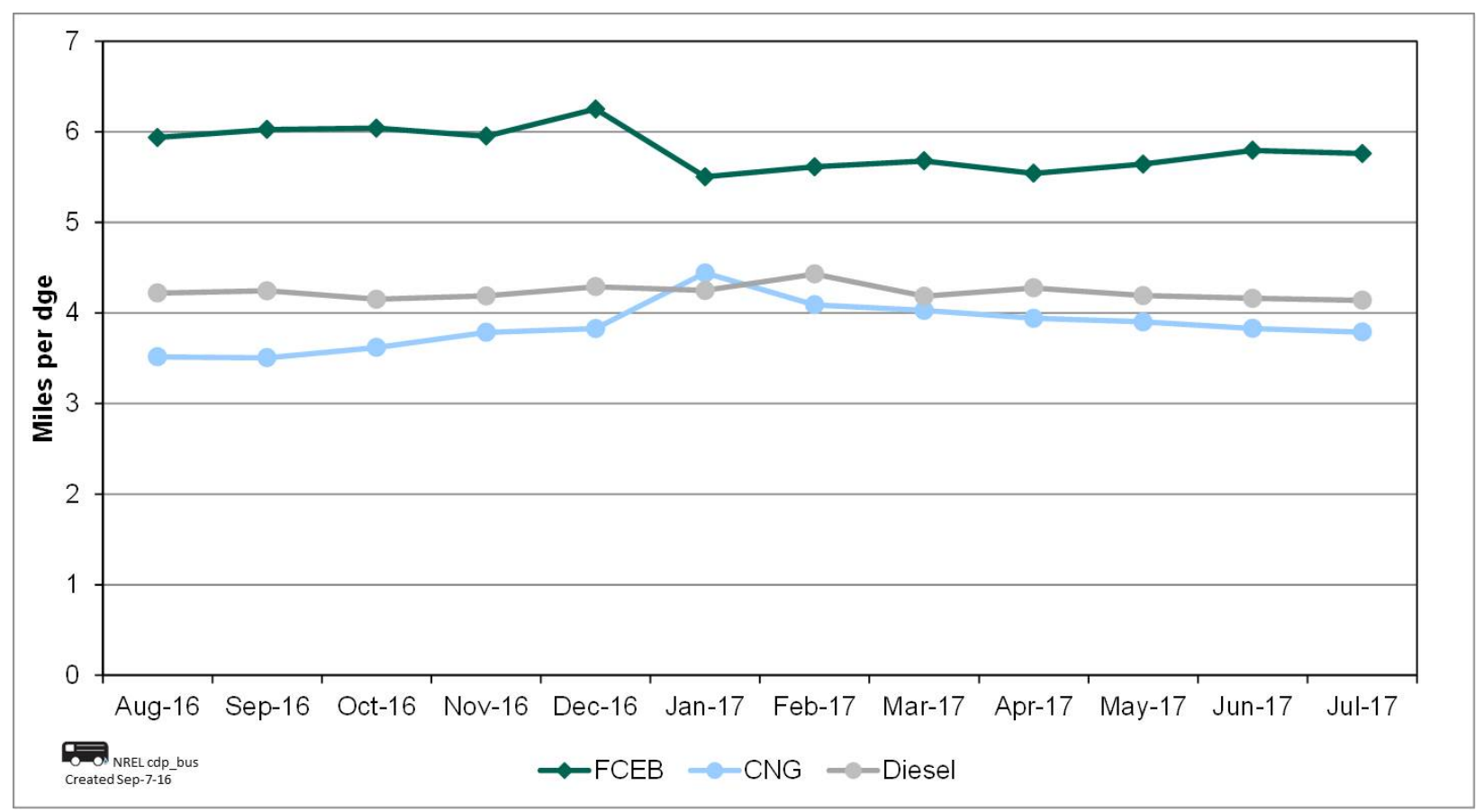

Figure 6. Fuel economy for the FCEBs and baseline buses

The average fuel economy for the fleet has continued to decrease over time. This decrease could be due to a variety of factors that include the following:

- Duty cycle-Fuel economy is highly dependent on duty cycle. Characteristics of the routes, such as average speed, terrain, number of stops, and passenger loading, have an effect on efficiency.

- Operators-Differences in driving styles of the operators could influence efficiency.

- Temperature - Higher ambient temperatures result in increased auxiliary loads for air conditioning.

- Fuel cell power plant (FCPP) degradation-As fuel cells age, the ability to provide the same power decreases. 
- Hydrogen station metering differences between stations-Accurately measuring the amount of hydrogen dispensed has been a challenge for the industry.

\section{Maintenance Cost}

In past FCEB status reports, NREL has referenced cost data presented in detail in individual site reports. For this report, NREL updated the analysis for each fleet through July 2017, and the detailed costs are presented in this section. The maintenance data from the UCI and MBTA buses are not included because the data sets for those buses are not complete.

NREL collects and analyzes all work orders for the FCEBs and baseline buses. The maintenance analysis eliminates costs for accident-related repair, which are extremely variable from bus to bus and are not relevant to the technology comparison. For consistency between evaluations, NREL sets the maintenance labor rate at $\$ 50$ per hour. This does not reflect an average rate for any of the evaluation sites. Warranty costs are generally not included in the cost-per-mile calculations because they are covered in the purchase price of the buses. The AC Transit ZEBA buses are now beyond the term for the original warranty, therefore costs have increased. More expensive parts and added labor hours for training mechanics are the primary drivers for the cost increase. The AFCBs at the other agencies are still under warranty and most parts are covered by the OEM. To differentiate between the buses out of warranty and those under warranty, NREL has separated the costs for the AFCBs and AC Transit buses. The baseline buses in this section include the diesel fleet at AC Transit and the newer CNG buses at SunLine and OCTA. The newer CNG buses at SunLine and OCTA are the same manufacturer and model and are similar in specifications. NREL has combined the data for these two CNG fleets and labeled it as New CNG. For comparison, NREL has also included a data set from older CNG buses operated by SunLine. NREL ended data collection on the older CNG buses at the end of 2016. Table 11 outlines the data sets used in the analysis.

Table 11. Fleet Data Sets Used in the Maintenance Analysis

\begin{tabular}{|l|c|c|c|c|c|c|c|}
\hline $\begin{array}{c}\text { Fleet } \\
\text { Name }\end{array}$ & Agency & $\begin{array}{c}\text { No. of } \\
\text { Buses }\end{array}$ & $\begin{array}{c}\text { Data Set } \\
\text { Start Date }\end{array}$ & $\begin{array}{c}\text { Data Set } \\
\text { End Date }\end{array}$ & $\begin{array}{c}\text { Total } \\
\text { Months }\end{array}$ & Dates of Analysis & $\begin{array}{c}\text { Under } \\
\text { Warranty }\end{array}$ \\
\hline \multirow{2}{*}{ AFCB } & SunLine & 4 & $3 / 1 / 2012$ & $7 / 1 / 2017$ & 65 & Aug 2016-Jul 2017 & Yes \\
\cline { 2 - 8 } & OCTA & 1 & $5 / 1 / 2016$ & $7 / 1 / 2017$ & 15 & Aug 2016-Jul 2017 & Yes \\
\hline $\begin{array}{l}\text { Van Hool } \\
\text { FCEB }\end{array}$ & AC Transit & 13 & $9 / 1 / 2010$ & $7 / 1 / 2017$ & 83 & Aug 2016-Jul 2017 & No \\
\hline Diesel & AC Transit & 10 & $7 / 1 / 2013$ & $7 / 1 / 2017$ & 49 & Aug 2016-Jul 2017 & No \\
\hline $\begin{array}{l}\text { New } \\
\text { CNG }\end{array}$ & SunLine & 5 & $1 / 1 / 2017$ & $7 / 1 / 2017$ & 7 & Jan 2017-Jul 2017 & Yes \\
\hline & OCTA & 10 & $5 / 1 / 2016$ & $7 / 1 / 2017$ & 15 & Aug 2016-Jul 2017 & Yes \\
\hline Old CNG & SunLine & 5 & $11 / 1 / 2008$ & $12 / 1 / 2016$ & 98 & $\begin{array}{c}\text { Jan 2016-Dec } \\
2016\end{array}$ & No \\
\hline
\end{tabular}

This section first covers total maintenance costs and then maintenance costs by bus system.

\section{Total Work Order Maintenance Costs}

Total maintenance costs include the price of parts and labor rates at \$50 per hour. NREL calculates the cost per mile as follows:

$$
\text { Cost per mile }=[(\text { labor hours } * 50)+\text { parts cost }] / \text { mileage }
$$


Table 12 shows total maintenance costs for the FCEBs and baseline buses. The table includes total cost and also separates scheduled and unscheduled maintenance cost per mile by fleet. Scheduled maintenance includes safety inspections and preventive maintenance at planned mileage intervals.

Table 12. Total Work Order Maintenance Cost

\begin{tabular}{|l|c|c|c|c|c|c|}
\hline \multicolumn{1}{|c|}{ Fleet } & Mileage & Parts (\$) & $\begin{array}{c}\text { Labor } \\
\text { Hours }\end{array}$ & $\begin{array}{c}\text { Total } \\
\text { Cost per Mile } \\
(\$)\end{array}$ & $\begin{array}{c}\text { Scheduled } \\
\text { Cost per Mile } \\
(\$)\end{array}$ & $\begin{array}{c}\text { Unscheduled } \\
\text { Cost per } \\
\text { Mile (\$) }\end{array}$ \\
\hline AFCB & 117,834 & 15,255 & 1,011 & 0.56 & 0.11 & 0.45 \\
\hline Van Hool FCEB & 451,533 & 253,291 & 6,261 & 1.25 & 0.27 & 0.98 \\
\hline Diesel & 473,199 & 101,076 & 3,525 & 0.59 & 0.14 & 0.45 \\
\hline Old CNG & 319,864 & 70,747 & 1,540 & 0.46 & 0.08 & 0.38 \\
\hline New CNG & 575,928 & 41,837 & 2,447 & 0.29 & 0.13 & 0.26 \\
\hline
\end{tabular}

Figure 7 provides the scheduled and unscheduled cost per mile by fleet for the data period. The Van Hool FCEB fleet has the highest total maintenance cost, followed by the AFCB, diesel, older CNG, and newer CNG fleets. As mentioned earlier, the Van Hool FCEBs, diesel buses, and older CNG buses are all out of the warranty period. High parts cost and added labor hours for training were the primary factors for the higher costs for the Van Hool FCEBs. The new CNG buses went into service in late 2016/early 2017 and are under warranty. The higher scheduled cost for the new CNG buses compared to the older CNG buses is primarily due to the added scheduled maintenance for changing spark plugs on the Cummins ISLG engine, which is more frequent than for previous $\mathrm{CNG}$ engines. 


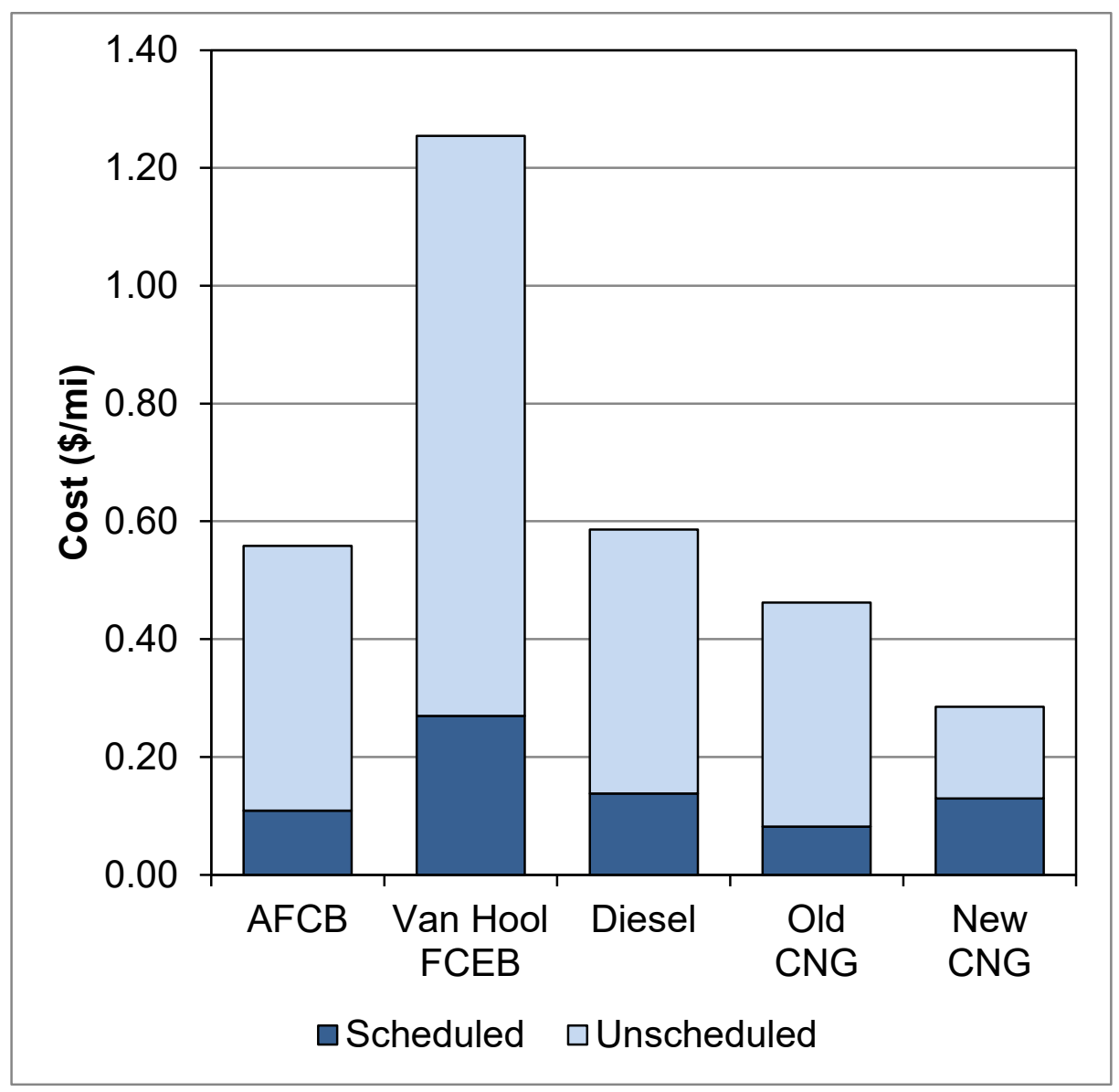

Figure 7. Scheduled and unscheduled costs

Figure 8 provides the cost per mile separated by parts and labor. The chart illustrates that the high parts costs significantly affect the Van Hool FCEB and old CNG bus costs. Nearly half of the total cost for the Van Hool FCEBs (45\%) is attributed to parts, compared to $48 \%$ for the older CNG buses, $36 \%$ for the diesel buses, $25 \%$ for the newer CNG buses, and $23 \%$ for the AFCBs. 


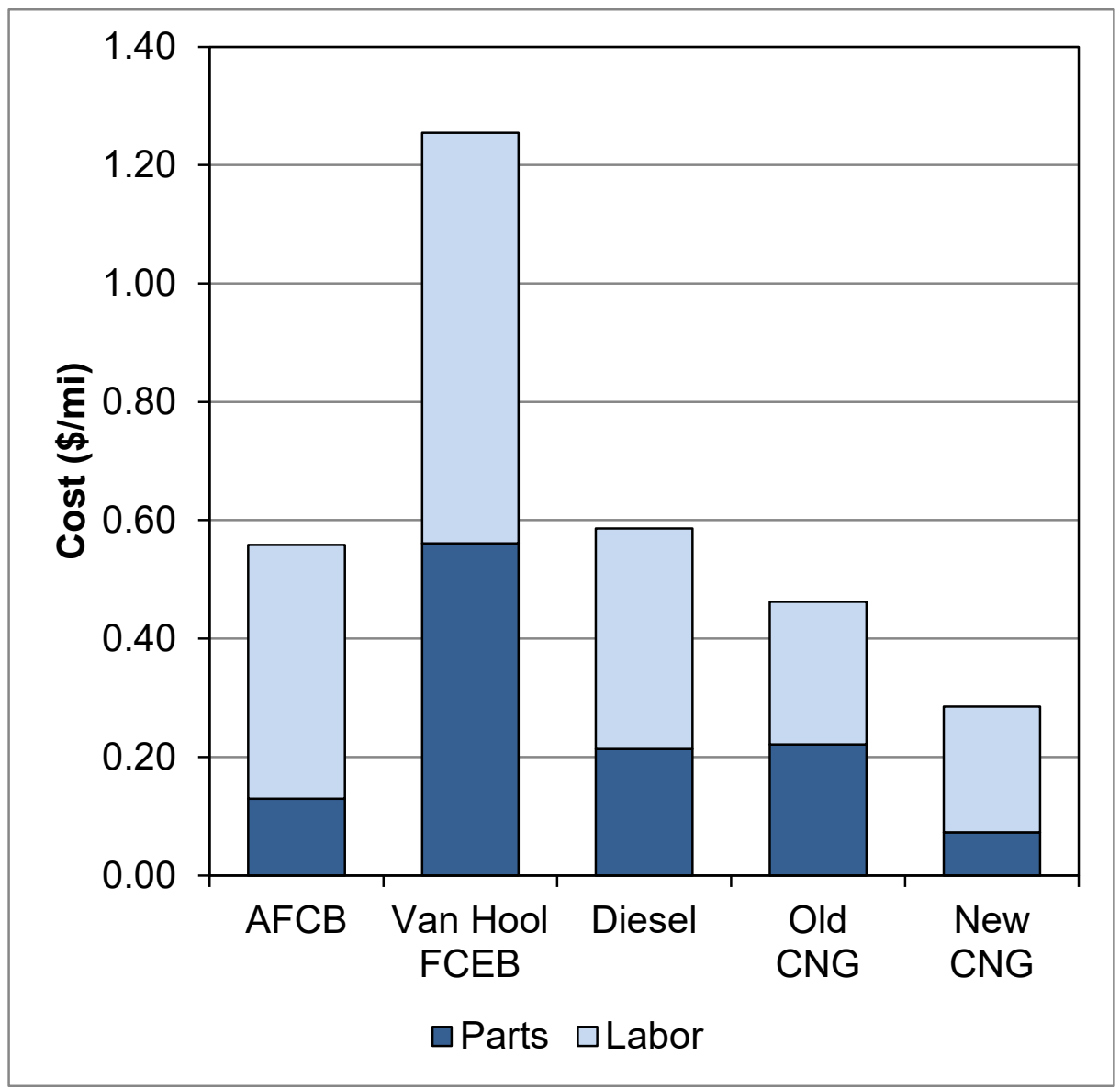

Figure 8. Parts and labor costs per mile

\section{Work Order Maintenance Costs Categorized by System}

Table 13 shows maintenance costs by vehicle system and bus study group (without warranty costs). Figure 9 presents the data graphically. The vehicle systems shown in the table are as follows:

- Cab, body, and accessories: Includes body, glass, and paint repairs; cab and sheet metal repairs on seats and doors; and accessory repairs such as hubodometers, fareboxes, and radios

- Propulsion-related systems: Repairs for exhaust, fuel, engine, electric motors, fuel cell modules, propulsion control, non-lighting electrical (charging, cranking, and ignition), air intake, cooling, and transmission

- Preventive maintenance inspections (PMI): Labor for inspections during preventive maintenance (parts for scheduled maintenance, such as filters and fluids, are included in the specific system categories; for example, oil and oil filters are included in the engine subsystem parts costs, while air filters are included in the air subsystem parts costs.)

- Brakes

- Frame, steering, and suspension 
- Heating, ventilation, and air conditioning (HVAC)

- Lighting

- Air system, general

- Axles, wheels, and drive shaft

- Tires.

Table 13. Work Order Maintenance Cost per Mile by System (Report Data Period) ${ }^{14}$

\begin{tabular}{|l|c|c|c|c|c|}
\hline \multicolumn{1}{|c|}{ System } & AFCB & $\begin{array}{c}\text { Van } \\
\text { Hool } \\
\text { FCEB }\end{array}$ & Diesel & $\begin{array}{c}\text { Old } \\
\text { CNG }\end{array}$ & $\begin{array}{c}\text { New } \\
\text { CNG }\end{array}$ \\
\hline Propulsion-related & 0.13 & 0.25 & 0.15 & 0.10 & 0.08 \\
\hline Cab, body, and accessories & 0.19 & 0.42 & 0.15 & 0.26 & 0.08 \\
\hline PMI & 0.11 & 0.18 & 0.08 & 0.07 & 0.09 \\
\hline Brakes & 0.04 & 0.04 & 0.08 & 0.03 & 0.02 \\
\hline Frame, steering, and suspension & 0.06 & 0.05 & 0.01 & 0.04 & 0.00 \\
\hline HVAC & 0.01 & 0.02 & 0.02 & 0.03 & 0.00 \\
\hline Lighting & 0.00 & 0.01 & 0.01 & 0.01 & 0.00 \\
\hline General air system repairs & 0.00 & 0.14 & 0.00 & 0.00 & 0.00 \\
\hline Axles, wheels, and drive shaft & 0.01 & 0.15 & 0.07 & 0.00 & 0.01 \\
\hline Tires & 0.00 & 0.00 & 0.00 & 0.01 & 0.00 \\
\hline Total & $\mathbf{0 . 5 6}$ & $\mathbf{1 . 2 5}$ & $\mathbf{0 . 5 9}$ & $\mathbf{0 . 5 4}$ & $\mathbf{0 . 2 9}$ \\
\hline
\end{tabular}

The color shading denotes the systems with the highest percentage of maintenance costs: orange for the highest, green for the second highest, and purple for the third highest. The systems with the highest percentage of maintenance costs for all groups except the new CNG buses were 1) propulsion-related; 2) cab, body, and accessories; and 3) PMI. The systems with the highest percentage of maintenance costs for the new CNG buses were 1) PMI; 2) propulsion-related; and 3 ) cab, body, and accessories. The diesel buses had similar costs for the propulsion-related and cab, body, and accessories systems.

\footnotetext{
${ }^{14}$ Most of the values shown as zero are not necessarily zero, but they are so low that they round to zero.
} 


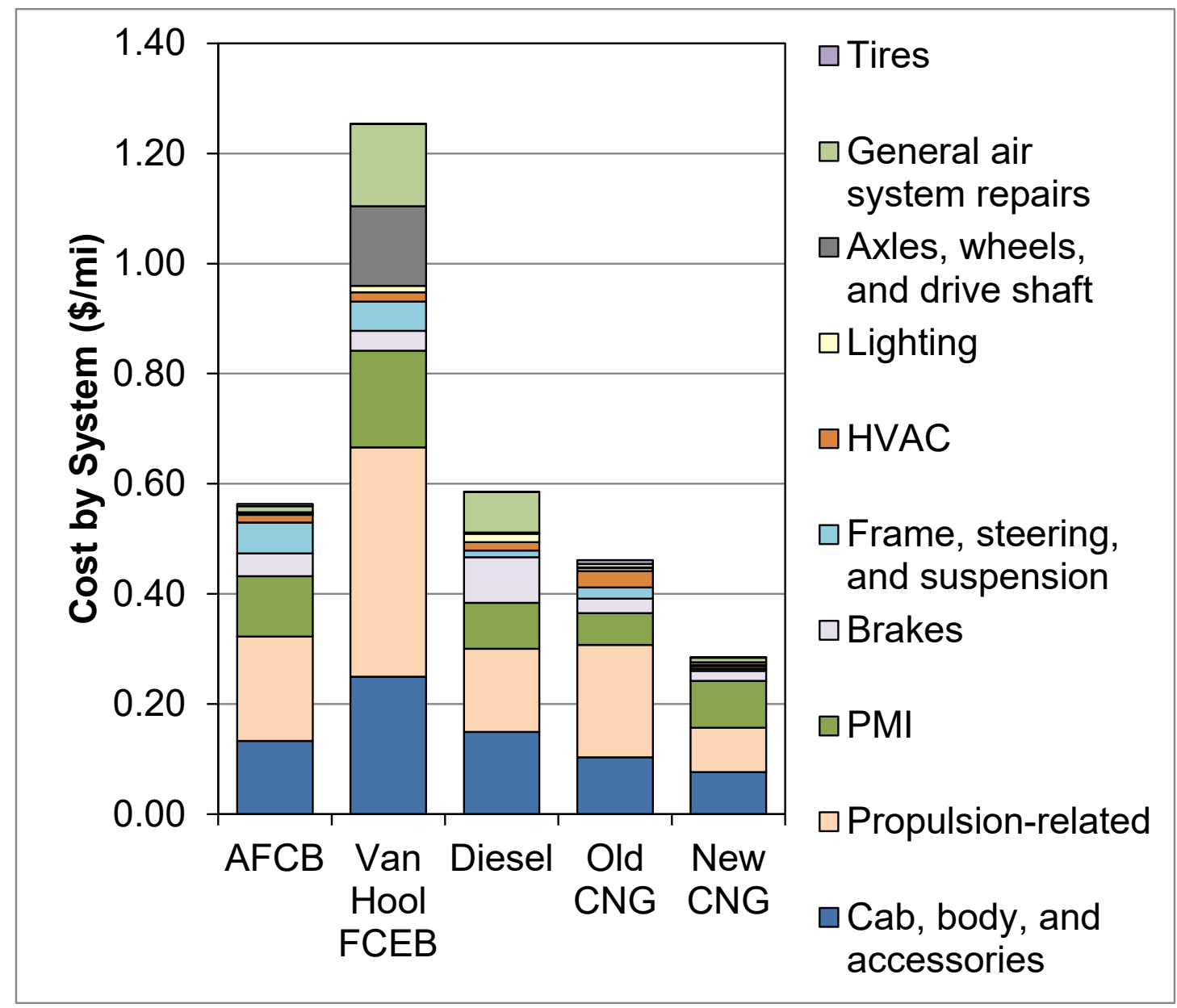

Figure 9. Maintenance cost per mile by system

\section{Propulsion-Related Work Order Maintenance Costs}

Propulsion-related vehicle systems include the exhaust, fuel, engine, electric propulsion, air intake, cooling, non-lighting electrical, and transmission systems. These systems have been separated to highlight maintenance costs most directly affected by the advanced propulsion system changes for the buses. Figure 10 shows the propulsion-related system maintenance by subsystem for the groups of buses during the data period. The subsystems with the highest percentage of maintenance costs for the AFCB were fuel cell, cooling, and cranking/charging. For the Van Hool FCEBs, the highest-cost subsystems were fuel cell, cooling, and electric drive. The diesel buses had the highest maintenance costs for the fueling, cooling, and engine subsystems. For the older CNG buses, the highest cost subsystems were engine, exhaust, and cranking/charging. The newer CNG buses had the highest maintenance costs in the engine, transmission, and cranking/charging subcategories. 


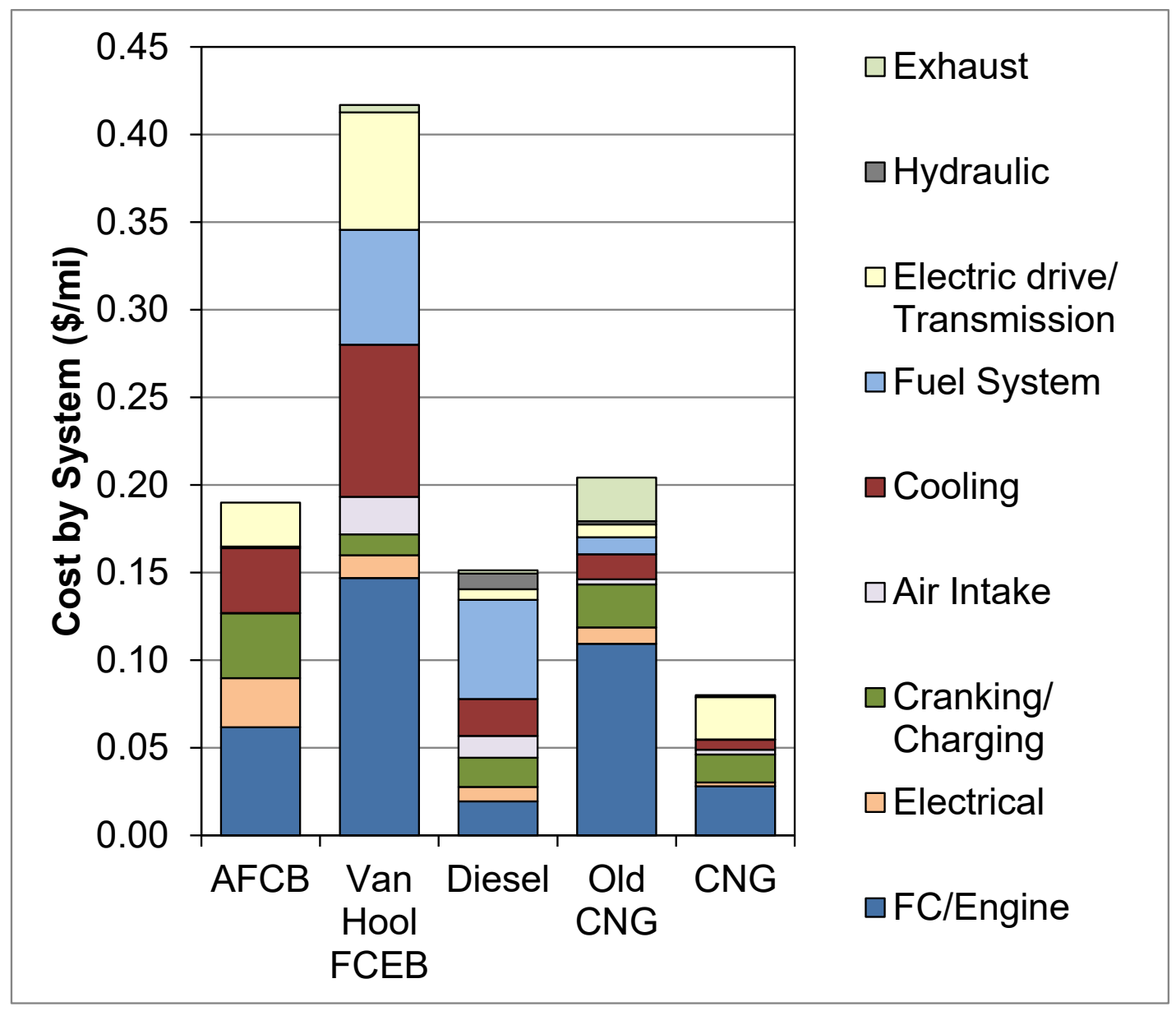

Figure 10. Propulsion system cost per mile by sub-system

\section{Maintenance Costs over Time}

Comparing cost trends over time as the buses age can provide insight for an agency when planning to implement advanced technology buses. NREL has worked with AC Transit and SunLine since 2000 and has gathered data for multiple years on both FCEB and baseline fleets. Figure 11 through Figure 14 track the cost trends for the diesel, old CNG, AFCB, and Van Hool FCEB fleets respectively. The figures show the monthly cost per mile for scheduled and unscheduled maintenance since NREL first began data collection. The cumulative cost per mile is included to show the overall trend. The average odometer for each fleet is tracked to indicate age of the buses. For easier comparison between the figures, the cost axes are capped at $\$ 2.50$ per mile, although both the AFCB and Van Hool FCEB charts have one month that exceeds that amount. The actual amount for those months is included in the figures. Maintenance practices for each transit agency differ, which results in cost variations. For example, agencies that are diligent in performing preventive maintenance tasks often have lower unscheduled costs and higher reliability. Larger agencies often find it challenging to train mechanics to work on advanced technology buses when the new fleet size is small. Previous experience with gaseousfueled buses and hybrid electric buses typically helps an agency learn to work on FCEBs faster. All these factors influence the cost per mile and the reader should consider this when making comparisons. 
Figure 11 shows the costs over time for the AC Transit Gillig diesel buses. NREL has collected 5 years of data on these buses, which are nearing the halfway point in their useful life (FTA bus lifetime requirements are 12 years or 500,000 miles). The costs for the buses are low during the first 2 years while they are under warranty and have low mileage. Scheduled costs are consistent, showing the familiarity of the mechanics with diesel technology. The cumulative cost shows a slow and steady increase over time. This is the expected trend for a mature technology such as diesel. Unscheduled costs are higher after the warranty period as parts costs are no longer covered by the OEM. The buses have surpassed several key mileage points where tune-ups and other major repairs are needed. These buses are equipped with emission control equipment required to meet U.S. Environmental Protection Agency standards.

Emissions are reduced through exhaust gas recirculation, diesel particulate traps, and selective catalytic reduction. Maintenance work on the emissions equipment has contributed to the increased cost of the buses.

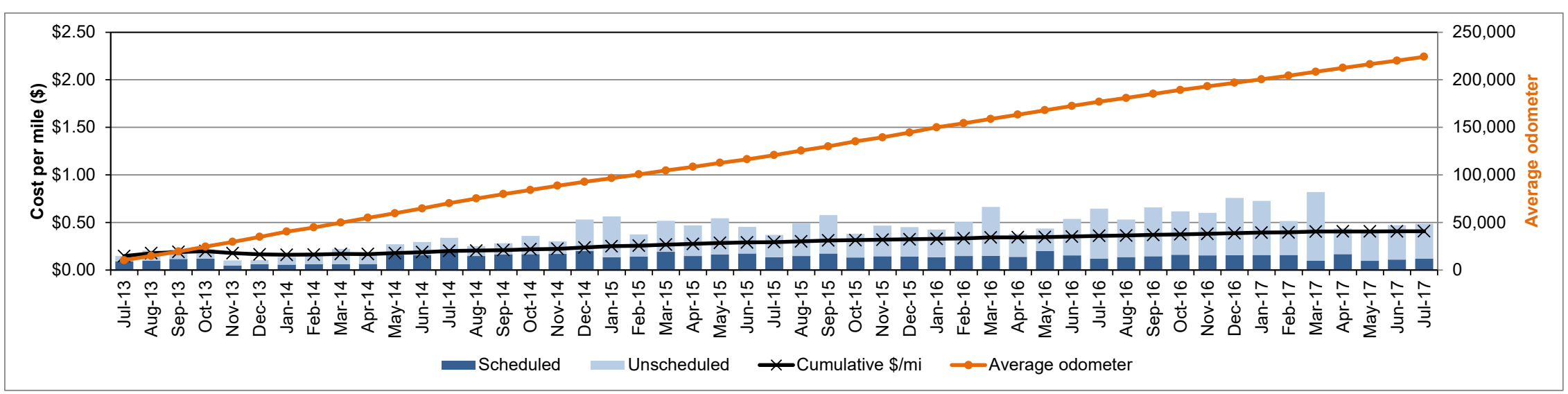

Figure 11. Monthly scheduled and unscheduled cost per mile for the diesel buses 
Figure 12 tracks the costs over time for the older CNG buses at SunLine. NREL began collecting data on these buses when they were new as a baseline for SunLine's previous FCEB demonstration. NREL has more than 8 years of data on these buses, which are nearing the end of their useful life. Because of the advanced age of the buses, NREL ended data collection in December 2016 and began evaluating the newer CNG buses as the SunLine baseline bus fleet. The large data set provides a unique opportunity to show the CNG bus trend through most of the fleet's life. Like diesel buses, CNG buses are a very mature technology. SunLine has extensive experience with the technology and its mechanics are very familiar with maintenance requirements. Scheduled maintenance is consistent over time and cumulative costs show a steady increase as unscheduled costs increase with age.

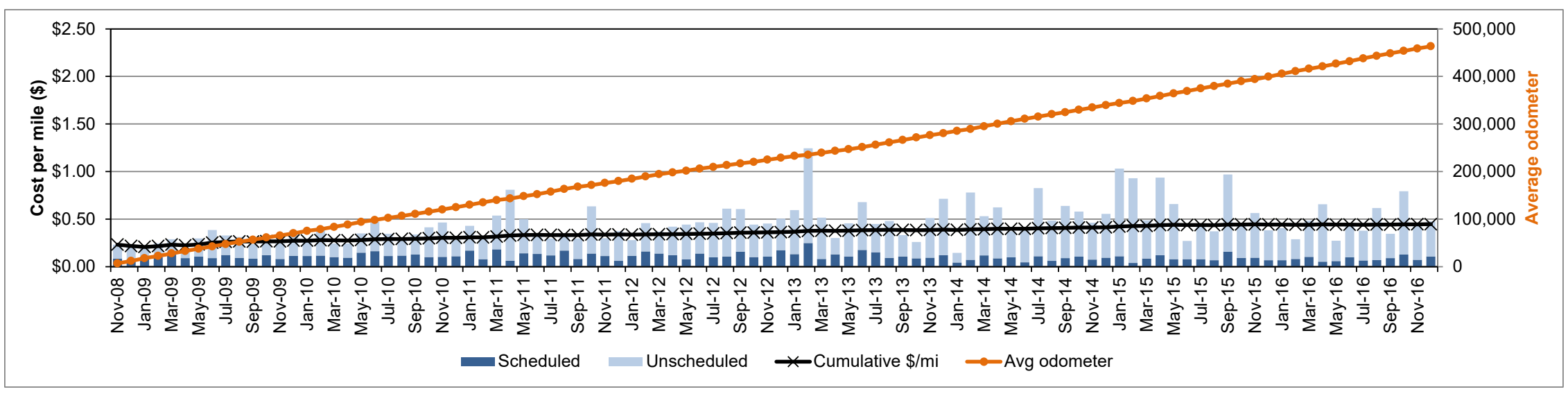

Figure 12. Monthly scheduled and unscheduled cost per mile for the older CNG buses 
Figure 13 tracks the SunLine and OCTA AFCB cost over time. The chart begins with the in-service date of the prototype bus at SunLine, which was the only AFCB operating until May 2014 when the next bus went into service. The average odometer drops with every additional AFCB added to the data set. All AFCBs were in service by May 2016. The figure shows variable monthly costs with a consistent cumulative cost per mile. The buses were all under warranty during the entire data period; therefore, labor hours and miles of operation primarily drive the costs. The prototype bus developed a coolant leak in mid-2013 and was removed from service for several months (note the blank section on the chart). The agency eventually traced the leak to a cracked radiator. The leak proved challenging to locate partly because of SunLine's location in the desert region of the Coachella Valley. The hot climate meant the usual method of diagnosing a leak - through visual evidence - was difficult because any pooled liquid quickly evaporated. In November 2013, the transit agency spent significant labor hours to troubleshoot the issue. These labor hours with minimal miles resulted in the high cost per mile for that month $(\$ 4.66 / \mathrm{mile})$. To eliminate this problem, new AFCBs have an upgraded radiator cradle to increase integrity. SunLine's maintenance workers came up to speed on the FCEB technology quickly because of their extensive experience with both CNG buses and previous FCEB demonstrations.

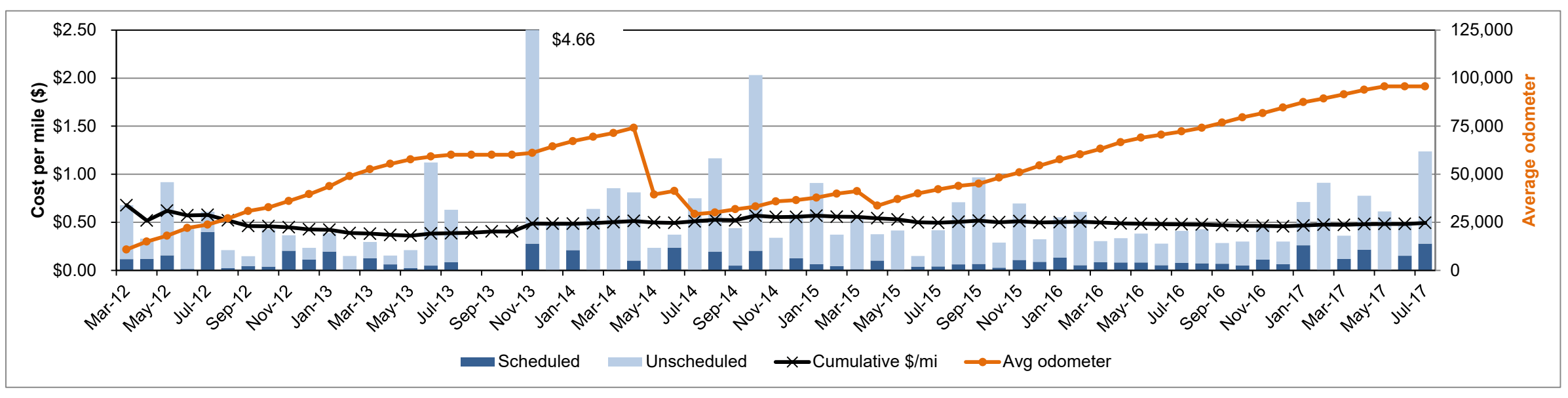

Figure 13. Monthly scheduled and unscheduled cost per mile for the AFCBs 
Figure 14 tracks the costs over time of the Van Hool FCEBs operated by AC Transit. The agency phased in the fleet of 12 buses over the first year of operation. The agency added a $13^{\text {th }}$ bus in October 2015 after it ended its two-year demonstration in Connecticut. AC Transit's hydrogen station was out of service from June 2012 through January 2013, resulting in the need to remove the buses from service. AC Transit is one of the larger fleets to operate FCEBs. The costs for this fleet change based on the different phases in the program. Early in the demonstration (Phase 1), the agency selected a small group of technicians to learn the new technology. Those mechanics spent time training with on-site manufacturer staff. The cost trend during this time started high and then dropped as the selected maintenance staff became more familiar with the technology. On-site manufacturer staff handled most of the work, but labor hours for training transit staff increased the cost. During Phase 2 (hydrogen station downtime), the buses did not accumulate miles but the cumulative cost increased because the mechanics used the downtime to troubleshoot and repair some of the early issues with several buses. In Phase 3, the select maintenance staff handled nearly all scheduled work and became much more familiar with the other aspects of maintaining the FCEBs. Some work was still covered under warranty including some parts. During this phase, cumulative costs were steadily dropping. By Phase 4, the warranty period had ended and parts costs resulted in a large increase for unscheduled costs. High parts costs are the primary reason for the higher cost per mile for the FCEBs. Another factor is the added labor hours for troubleshooting issues and for training. AC Transit split the fleet between two depots in February 2015, which required training more staff to handle maintenance. As the agency ramped up training outside the original group of mechanics, labor hours could double or triple depending on the number of maintenance staff being trained during each maintenance event. For these cases, the time and cost of the repairs will be artificially high. These labor costs will eventually drop and stabilize as staff experience increases.

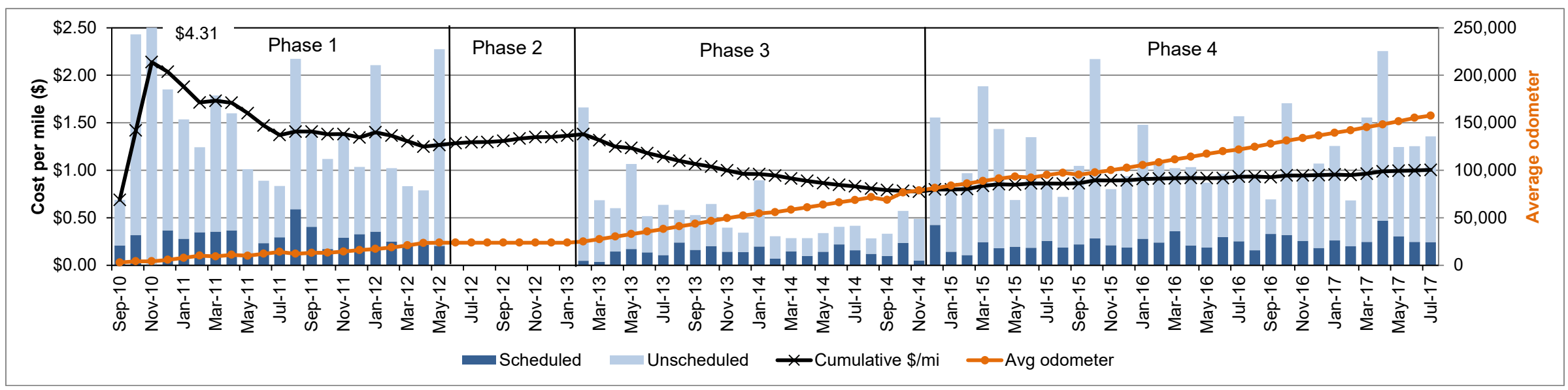

Figure 14. Monthly scheduled and unscheduled cost per mile for the Van Hool FCEBs 


\section{Current Status of FCEB Introductions: Summary of Achievements and Challenges}

FCEB technology continues to show progress toward meeting technical targets for reliability and durability while also decreasing in cost. This section discusses the progress being made and the challenges that remain to bring FCEBs to the market.

\section{Progress Toward Meeting Technical Targets}

In 2012, DOE and FTA established performance and cost targets for FCEBs. ${ }^{15}$ Interim targets were set for 2016 along with ultimate targets that FCEBs would need to meet to compete with current commercial-technology buses. Although the targets set in 2012 included a 2016 interim target, not all FCEBs were expected to reach these targets in that timeframe. In particular, the power plant lifetime requires 6 years/250,000 miles before reaching the target. Table 14 shows a selection of these technical targets for FCEBs.

Table 14. DOE/FTA Performance, Cost, and Durability Targets for FCEBs ${ }^{a}$

\begin{tabular}{|l|c|c|c|}
\hline & Units & 2016 Target & $\begin{array}{c}\text { Ultimate } \\
\text { Target }\end{array}$ \\
\hline Bus lifetime & years/miles & $12 / 500,000$ & $12 / 500,000$ \\
\hline Power plant lifetime ${ }^{\mathrm{b}}$ & hours & 18,000 & 25,000 \\
\hline Bus availability & $\%$ & 85 & 90 \\
\hline Fuel fills & per day & $1(<10 \mathrm{~min})$ & $1(<10 \mathrm{~min})$ \\
\hline Bus cost & $\$$ & $1,000,000$ & 600,000 \\
\hline $\begin{array}{l}\text { Roadcall frequency } \\
\text { (bus/fuel cell system) }\end{array}$ & $\begin{array}{c}\text { miles between } \\
\text { roadcalls (MBRC) }\end{array}$ & $3,500 / 15,000$ & $4,000 / 20,000$ \\
\hline Operation time & $\begin{array}{c}\text { hours per day/ } \\
\text { days per week }\end{array}$ & $20 / 7$ & $20 / 7$ \\
\hline $\begin{array}{l}\text { Scheduled and } \\
\text { unscheduled } \\
\text { maintenance cost }\end{array}$ & \$/mile & 0.75 & 0.40 \\
\hline Range & miles & 300 & 300 \\
\hline Fuel economy & miles per dge & 8 & 8 \\
\hline
\end{tabular}

a The cost targets for subsystems (power plant and hydrogen storage) are not included.

b The power plant is defined as the fuel cell system and the battery system.

${ }^{c}$ Cost is projected to a production volume of 400 systems per year. This production volume is assumed for analysis purposes only and does not represent an anticipated level of sales.

${ }^{d}$ Excludes mid-life overhaul of power plant.

Table 15 presents the current status for the FCEBs toward meeting the DOE/FTA targets. The data are presented for the FCEB fleets as a group - that is, data are combined for all 19 buses. The table includes the fleet minimum and maximum as well as the overall average for the buses as a group. The data for this section include the life and performance beginning at the clean point for each bus.

\footnotetext{
${ }^{15}$ Fuel Cell Technologies Program Record \# 12012, September 12, 2012.
} 
Table 15. Current Status Toward Meeting Performance Targets ${ }^{16}$

\begin{tabular}{|l|c|c|c|}
\hline & $\begin{array}{c}\text { Fleet } \\
\text { Minimum }\end{array}$ & $\begin{array}{c}\text { Fleet } \\
\text { Maximum }\end{array}$ & $\begin{array}{c}\text { Fleet } \\
\text { Average }\end{array}$ \\
\hline Bus lifetime (years) & 0.7 & 7.0 & 4.9 \\
\hline Bus lifetime (miles) & 16,975 & 189,168 & 131,963 \\
\hline Power plant lifetime (hours) & 599 & 25,395 & 14,309 \\
\hline Bus availability (\%) & 42 & 93 & 75 \\
\hline Fuel fills (number per day) & 1 & 1 & 1 \\
\hline Bus cost (\$) & $2.1 \mathrm{M}$ & $2.4 \mathrm{M}$ & $2.25 \mathrm{M}$ \\
\hline Roadcall frequency-bus (MBRC) & 1,179 & 8,739 & 4,649 \\
\hline Roadcall frequency-fuel cell system (MBRC) & 7,661 & 23,741 & 21,260 \\
\hline Operation time (average hours per day) & 7.4 & 13.7 & 11.8 \\
\hline $\begin{array}{l}\text { Scheduled and unscheduled maintenance cost } \\
\text { (\$/mile) }\end{array}$ & 0.49 & 2.42 & 1.20 \\
\hline Range (miles) & 277 & 357 & 300 \\
\hline Fuel economy (miles per dge) & 5.83 & 7.82 & 7.01 \\
\hline
\end{tabular}

\section{Bus and Power Plant Lifetime}

The FTA minimum life cycle requirement for a full-size bus is 12 years or 500,000 miles. ${ }^{17}$ An FCPP needs to last about half that time; this compares to a diesel engine that is often rebuilt at about the mid-life of the bus. DOE/FTA set an ultimate performance target of 4 to 6 years (or 25,000 hours) for the fuel cell propulsion system durability, with an interim target of 18,000 hours by 2016. The FCPPs tracked by NREL continue to accumulate significant numbers of hours. NREL has now collected data on buses for more than half their useful life -6 years. Last year's report documented a single FCPP surpassing 23,000 hours without repair or cell replacement. At the end of the analysis period for this report (July 2017), that FCPP had surpassed the ultimate target of 25,000 hours. Nine FCPPs have now surpassed the 2016 DOE/FTA target of 18,000 hours and six of those have reached 20,000 hours. Three more FCPPs are close to reaching 18,000 hours. Figure 15 shows the total hours accumulated on the FCPPs for the AC Transit ZEBA fleet (blue bars), the SunLine AFCB fleet (orange bars), the UCI AFCB (green bar), the OCTA AFCB (purple bar), and the MBTA AFCB (light blue bar). The DOE/FTA targets for FCPP hours are highlighted in the figure as a green dashed line for the 2016 target and an orange dashed line for the ultimate target; the group average for the 19 FCPPs of 14,309 hours is shown as a red hashed line.

Other FCEB projects outside the United States have demonstrated advanced durability of fuel cells in transit applications. Ballard Power Systems recently announced that an FCPP in a bus operated by Transport for London had surpassed 25,000 hours with no major maintenance to the fuel cell stack. According to the press release, ${ }^{18}$ several other FCEBs are nearing the target.

\footnotetext{
${ }^{16}$ Fleet minimum and maximums are for each performance metric and may not necessarily be for the same bus.

${ }^{17}$ FTA Circular 5010.1D: Grant Management Requirements, page IV-17.

${ }^{18} \mathrm{http}: / / w w w . b a l l a r d . c o m / a b o u t-b a l l a r d / n e w s r o o m / n e w s-r e l e a s e s / 2017 / 08 / 29 /$ ballard-powered-fuel-cell-electricbus-achieves-25-000-hours-of-revenue-operation
} 


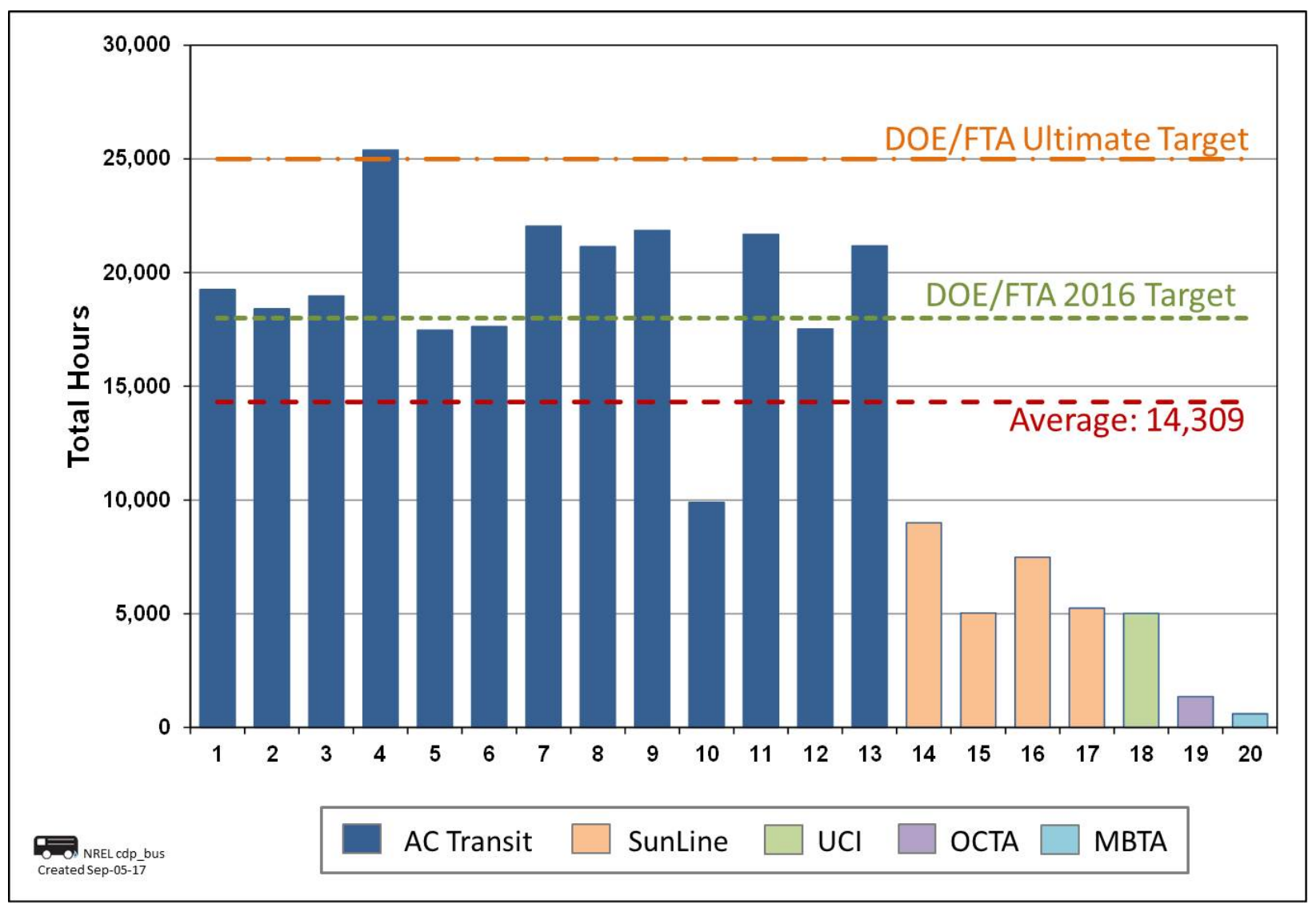

Figure 15. Total hours on the FCEBs through July 2017

\section{Bus Availability}

Availability for the 19 FCEBs ranges from a low of $42 \%$ to a high of $93 \%$ with an overall average of 75\%. Bus-related problems - such as brakes, suspension, air system, and air conditioning - make up the majority of unavailable days (45\%). Fuel cell system issues make up $27 \%$ of the unavailable time. Hybrid system problems - including issues with components such as traction motor, cooling system, and inverters - make up $15 \%$ of the unavailable days. Unavailability of parts has resulted in extended downtime in some cases. Transit staff continues to learn about the systems and become more proficient in troubleshooting and repairing issues. Downtime is expected to decrease over time.

\section{Fuel Fills}

Transit agencies typically fuel and service buses each evening to prepare them for morning pullout the following day. This results in a 6 to 8 hour window for all of the buses at a specific depot to be prepped for service. As the buses are being fueled, transit staff handles other prep work, such as cleaning the interior and emptying the farebox. The time to service each bus is about 10 minutes; therefore the fueling time needs to be 10 minutes or less. All transit agencies are able to fuel the buses at least once per day. Times for fueling vary between fleets, mainly due to the station designs. SunLine's station typically dispenses hydrogen at about 1 kilogram $(\mathrm{kg})$ per minute, resulting in an average fill time of 22 minutes. SunLine's station provides hydrogen using a reformer that has reached an advanced age. The agency has procured funding to upgrade 
the station. AC Transit's two stations can fill at higher rates, which results in fill times of less than 10 minutes. AC Transit reports that they have had issues with getting a full fill at the higher flow rates and have had to top off the buses in the morning to ensure a full fill. UCI operates a hydrogen station on campus that is primarily for fueling light-duty vehicles. The station was upgraded to allow bus fueling; however, high station use for cars results in the need for careful management of the bus fueling. The bus uses the same dispenser as the light-duty vehicles that fill at 350 bar pressure. The station can fill the bus with up to $32 \mathrm{~kg}$ in a fueling event, which requires a recovery period to replenish the hydrogen storage. Because of this, UCI limits bus fueling to a 4-hour window during late night hours. The average time to fuel the bus is 24 minutes. OCTA is in the planning process for building its hydrogen station. In the interim, the agency is using the UCI station, which is close to the facility where the AFCB operates. This requires extra time to get the bus fueled and the agency is limited to the same fueling window as the UCI AFCB is.

\section{Bus Cost}

DOE and FTA have set an interim capital cost target of $\$ 1$ million per bus with an ultimate target of $\$ 600,000$ per bus. Reported costs for FCEBs listed in Table 15 are based on the buses included in the data summary and have not changed since last year's report. At this point in the development of FCEB technology, costs are still high. The AC Transit buses cost \$2.5 million in 2010. OEMs report that more recent orders for FCEBs (through Low-No and California-funded programs) have had an average cost of $\$ 1.356$ million per bus, which is a $46 \%$ decrease. The capital cost should continue to decrease with larger orders of buses. The industry projects an order for 40 buses could result in costs closer to $\$ 1$ million each.

\section{Roadcall Frequency}

The transit industry measures reliability as mean distance between failures, also documented as MBRC. The DOE/FTA targets for roadcall frequency include MBRC for the entire bus and MBRC for the fuel cell system only. Bus MBRC includes all chargeable roadcalls, which means any issue that could physically disable the bus from operating on route. It does not include roadcalls for items such as fareboxes, radios, or destination signs. The fuel cell system MBRC includes any roadcalls due to issues with the fuel cell stack or associated balance of plant.

Each year, NREL presents summary data from the most recent evaluations. As demonstrations end, the data from those evaluations are removed from the combined calculations, while others are added. This makes it challenging to compare the current year's MBRC data to previous years because the data set can change significantly. To better illustrate the trend over time for the FCEB designs included in this report, the following MBRC results include reliability data from the current fleets back to the beginning of the evaluation periods. Figure 16 shows the monthly MBRC over time for the bus demonstrations combined. The DOE/FTA 2016 and ultimate targets for bus MBRC and fuel cell system MBRC are included as dashed lines on the chart. Bus MBRC continues to show a gradual upward trend, surpassing the 2016 target and reaching the ultimate target around the end of the previous data period (July 2015). The overall bus MBRC has remained steady over the last year. Fuel cell system MBRC continues to show an upward trend over time, surpassing the ultimate target in early 2015. Several fuel-cell-related roadcalls in 2016 caused this number to drop; however, it is still over the ultimate target. Over the last 6 months, the fuel cell system MBRC is increasing. 


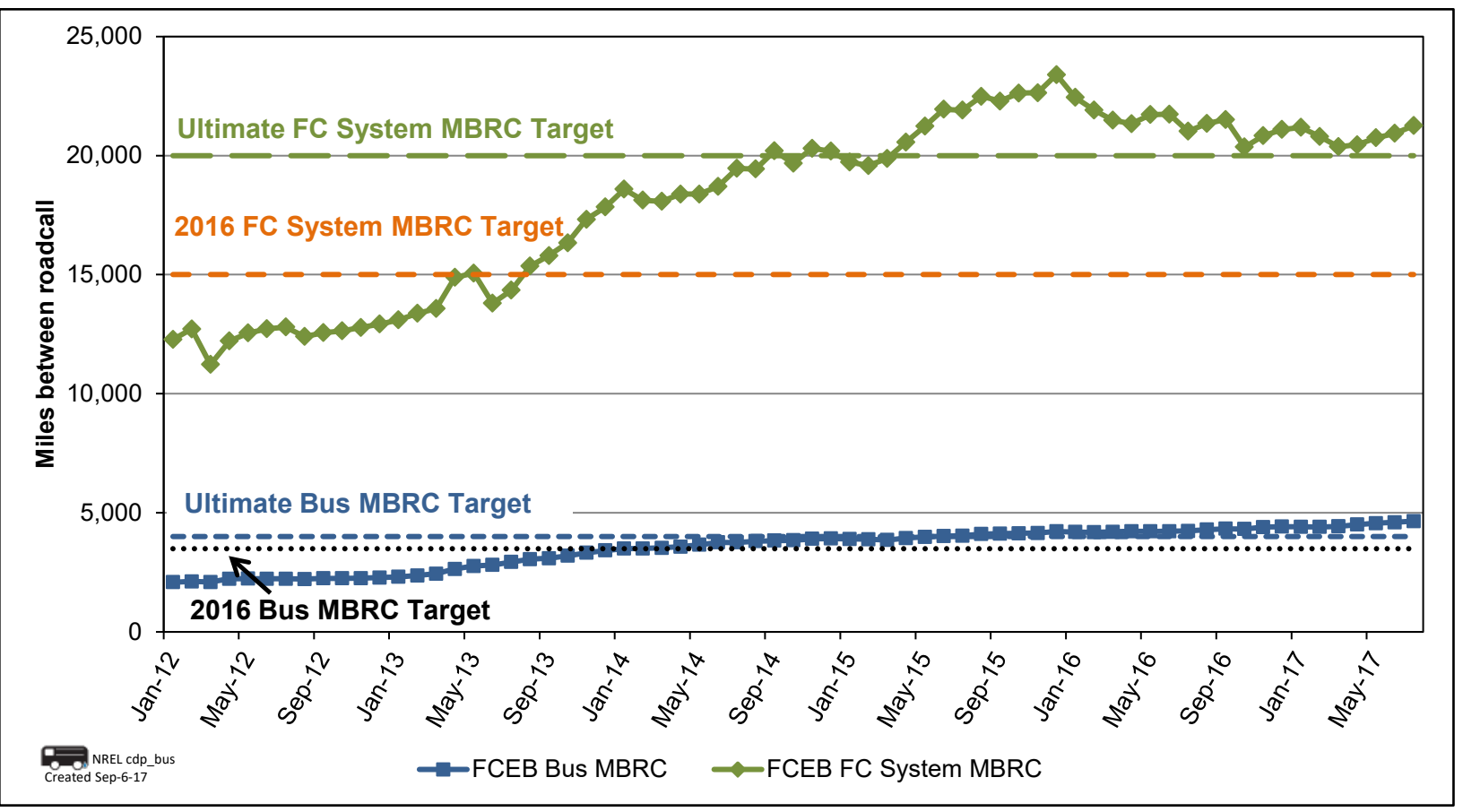

Figure 16. Monthly MBRC for the FCEBs

NREL tracks an additional metric of propulsion system MBRC. This category includes all roadcalls due to propulsion-related bus systems. Propulsion-related systems include the fuel cell system (or engine for a conventional bus), electric drive, fuel, exhaust, air intake, cooling, nonlighting electrical, and transmission systems. This metric is important because the primary difference between an advanced technology bus and a conventional bus is the propulsion system. NREL has documented propulsion system MBRC for conventional technologies from 10,000 to more than 20,000 miles. Table 16 summarizes the MBRC data from Figure 16 by year. For each year-long data period (ending in July), the table shows the cumulative bus MBRC, the propulsion system MBRC, and the fuel cell system MBRC, all calculated from the beginning of service.

Table 16. Summary of Cumulative MBRC for the Last 6 Years

\begin{tabular}{|l|c|c|c|c|c|c|}
\hline & $7 / 2012$ & $7 / 2013$ & $7 / 2014$ & $7 / 2015$ & $7 / 2016$ & $7 / 2017$ \\
\hline Bus MBRC & 2,230 & 2,937 & 3,762 & 4,037 & 4,242 & 4,648 \\
\hline Propulsion system MBRC & 3,346 & 4,484 & 6,217 & 6,583 & 7,086 & 7,820 \\
\hline Fuel cell system MBRC & 12,800 & 14,348 & 19,463 & 21,907 & 21,023 & 21,255 \\
\hline
\end{tabular}

\section{Operation Time}

The DOE/FTA target for bus operation is up to 20 hours per day for up to 7 days per week. SunLine and AC Transit report that the buses have operated as many as 21 hours in a single day. AC Transit's buses are scheduled on route blocks that operate from 3 to 21 hours per day. The overall fleet average is just under 12 hours per day. This is a reflection of the actual/planned operation, not the maximum capability of the FCEBs. SunLine's buses are planned for operation on weekdays, but they often operate on weekends as well. The SunLine AFCBs average 8 hours per day. Both agencies report that the buses regularly operate between 5 and 7 days per week. UCI schedules its bus to operate on a circulator route that travels from campus to nearby housing on weekdays only. The bus averages approximately 12 hours per day in service. The buses at 
OCTA and MBTA have not been on a consistent schedule and have not accumulated as many hours and miles as the buses at the other agencies.

\section{Scheduled and Unscheduled Maintenance Cost}

The costs in Table 15 cover data through July 2017. The AFCBs at SunLine and OCTA are all still under warranty, so nearly all of the maintenance costs are for labor. Maintenance costs for SunLine are currently $\$ 0.49$ per mile. The buses at AC Transit have reached the end of the original warranty period so parts costs have increased. The agency has negotiated extended contracts with the manufacturers, which has added to the overall maintenance costs. AC Transit's maintenance costs are $\$ 2.42$ per mile with the extended warranty costs included. The interim target is $\$ 0.70$ per mile and the ultimate target is $\$ 0.40$ per mile.

\section{Range and Fuel Economy}

In past reports, NREL has included the in-use fuel economy of the FCEBs during each report's data period for comparison to DOE/FTA targets. Over time, the fuel economy had dropped for the older buses. This is typical for any vehicle as it ages. While the primary driver for the decreasing fuel economy is aging of the buses and components, other factors also play a role such as changes in duty cycle, drivers, and weather. To better assess the fuel economy status and capability of the buses, NREL has analyzed the early results for the FCEBs when they were first placed into service. For this analysis, we used the first full year of data from each demonstration to determine an average fuel economy for the early life of the buses. Because fuel economy is highly variable by duty cycle, NREL calculated an overall fuel economy for each demonstration as opposed to one average for a particular FCEB design. Figure 17 presents the results of the fuel economy analysis and includes first- and second-generation FCEBs that NREL has evaluated. Table 17 outlines the demonstrations included in this analysis along with the average and median fuel economy for each generation. The fuel economy for the first-generation buses varied much more than for the second-generation buses. The average fuel economy for second-generation buses was 19\% higher than the average fuel economy for the first-generation buses. The lower fuel economy for a first-generation bus fleet that was not a hybrid design had a significant effect on the overall average. An estimated range can be calculated based on the fuel economy numbers and useful fuel amount ( $95 \%$ of the tank's capacity), resulting in an estimated average range for the second-generation buses of approximately 300 miles. 


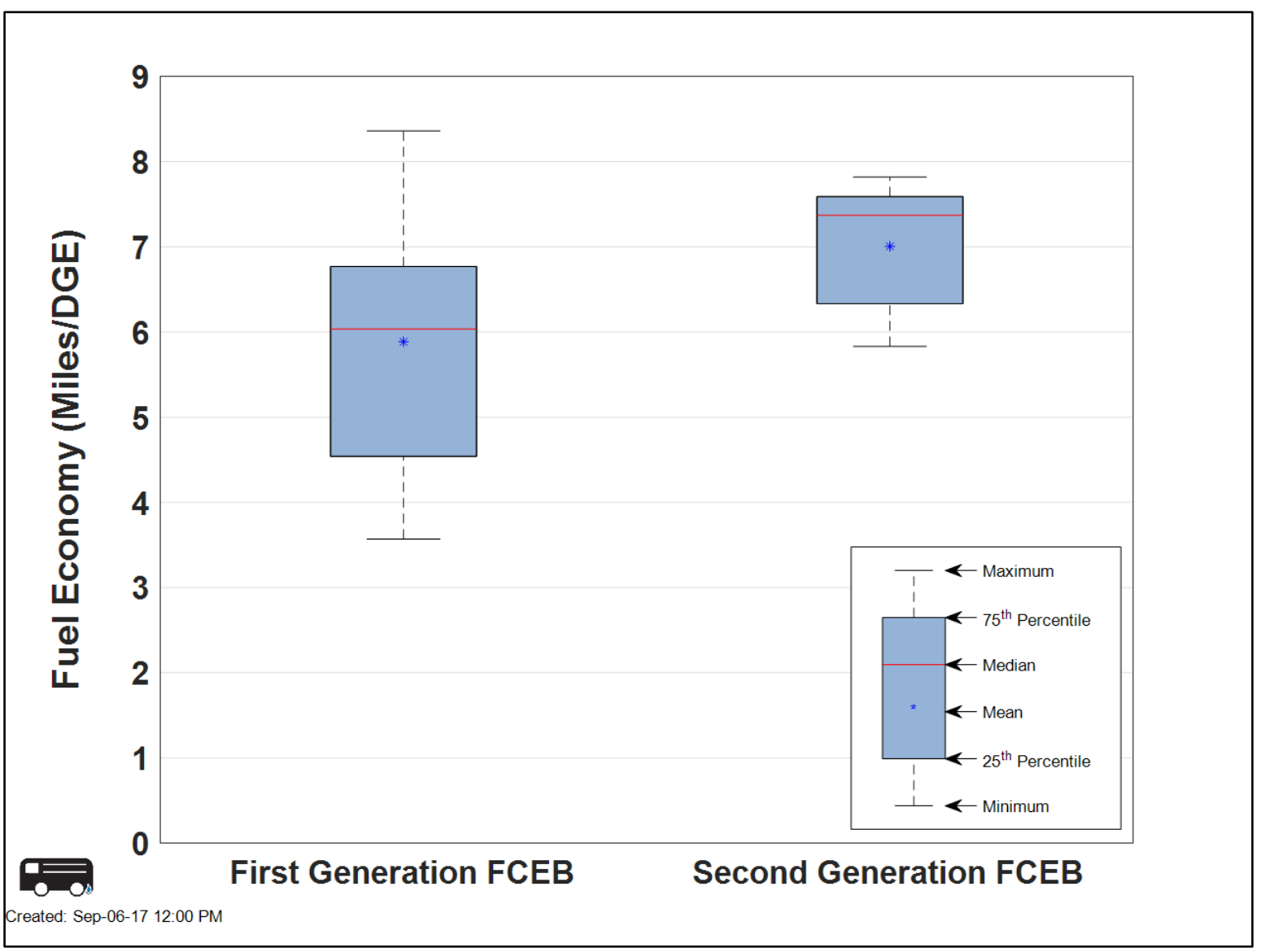

Figure 17. Fuel economy for the first- and second-generation FCEBs

Table 17. FCEB Demonstrations Included in the Fuel Economy Analysis

\begin{tabular}{|c|c|c|c|c|c|c|}
\hline $\begin{array}{l}\text { Demonstration } \\
\text { Site }\end{array}$ & OEMs & Dates & $\begin{array}{l}\text { Number } \\
\text { of Buses }\end{array}$ & Gen & $\begin{array}{l}\text { Average } \\
\text { Fuel } \\
\text { Economy } \\
\text { (miles } \\
\text { per dge) } \\
\end{array}$ & $\begin{array}{c}\text { Median } \\
\text { Fuel } \\
\text { Economy } \\
\text { (miles per } \\
\text { dge) } \\
\end{array}$ \\
\hline Santa Clara VTA ${ }^{a}$ & Gillig/Ballard & $3 / 05-2 / 06$ & 3 & \multirow{6}{*}{1} & \multirow{6}{*}{5.89} & \multirow{6}{*}{6.03} \\
\hline SunLine & New Flyer/Ballard & $5 / 10-4 / 11$ & 1 & & & \\
\hline $\begin{array}{l}\text { British Columbia } \\
\text { Transit }\end{array}$ & New Flyer/Ballard & $4 / 11-3 / 12$ & 20 & & & \\
\hline AC Transit & Van Hool/UTC Power & $4 / 06-3 / 07$ & 3 & & & \\
\hline SunLine & Van Hool/UTC Power & $4 / 08-3 / 09$ & 1 & & & \\
\hline Connecticut Transit & Van Hool/UTC Power & $1 / 08-12 / 08$ & 1 & & & \\
\hline AC Transit & Van Hool/UTC Power & $3 / 13-2 / 14$ & 12 & \multirow{5}{*}{2} & \multirow{5}{*}{7.01} & \multirow{5}{*}{7.37} \\
\hline Connecticut Transit & Van Hool/UTC Power & $1 / 11-12 / 11$ & 4 & & & \\
\hline SunLine & $\begin{array}{c}\text { ENC/BAE Systems/ } \\
\text { Ballard }\end{array}$ & variable & 4 & & & \\
\hline $\mathrm{UCl}$ & $\begin{array}{c}\text { ENC/BAE Systems/ } \\
\text { Ballard }\end{array}$ & $1 / 16-12 / 16$ & 1 & & & \\
\hline OCTA & $\begin{array}{c}\text { ENC/BAE Systems/ } \\
\text { Ballard }\end{array}$ & $6 / 16-5 / 16$ & 1 & & & \\
\hline
\end{tabular}

a This bus design was the only one that was not hybrid electric. VTA: Valley Transportation Authority. 


\section{Remaining Challenges}

FCEB performance continues to improve, and new FCEB designs have incorporated the early lessons learned from the first-generation systems. However, there are still challenges to overcome to make the technology commercially viable. This section outlines the ongoing challenges as well as lessons learned from recent issues that occurred over the last year.

Parts supply - Transit agencies continue to experience some issues with availability of bus components that have a long lead time for delivery. While this has improved for some components, agencies have taken the initiative to find other methods to supply parts. In some cases, an agency has sought to order parts directly from the component manufacturer instead of through a distributor. In other cases, an agency rebuilt or fabricated parts internally to reduce cost and downtime. Parts supply is particularly an issue for AC Transit because an OEM outside the United Sates produced its FCEBs. Upcoming FCEB projects are purchasing buses built by North American OEMs using the same platform as conventional technologies. Sharing of conventional bus parts will help improve availability of replacement parts and lower parts costs.

Deployment of larger fleets - To date, the majority of demonstrations in the United States involve smaller numbers of buses. To commercialize the technology, future deployments need to increase in fleet size - especially for larger agencies. Large transit agencies experience significant challenges with operating one or only a few advanced-technology buses that are different from those in its conventional fleets. It is hard to justify resources to train operators, mechanics, and schedulers to keep one unique bus in service. Any maintenance issue might result in the bus being parked until someone takes the time to troubleshoot and repair a problem, whether it involves the advanced technology components or not. Operators have trouble remembering the different operating characteristics when they don't drive the bus often. The primary goal for an agency is to meet daily planned service requirements and that one advancedtechnology bus may not be necessary to meet that goal. As a result, any agency without one or more internal champions for the technology will not get the same level of service from a new technology. This results in low mileage accumulation and availability. Deploying a larger fleet of FCEBs requires a commitment from all departments of an agency because the FCEBs are needed to meet the transit agency's planned service.

Maintenance costs for FCEBs - As reported last year, transit agencies operating FCEBs have made a concentrated effort to handle all the maintenance required for the buses. This results in a cost increase as transit staff takes on more of the maintenance responsibilities and begins the learning curve to understand how to maintain the buses. As the staff becomes more proficient, the costs eventually stabilize. The uncertainty for FCEBs at this point in development is how the parts costs will affect the overall maintenance costs over time once all the buses are out of the initial warranty period. The cost for parts for the older FCEBs dramatically increased once those buses were out of the warranty period. In some cases, the costs for advanced-technology parts are also much higher than the costs for conventional-technology parts. To help with future planning, transit agencies need to understand future costs as the technology moves into early commercial deployment. Standardization and manufacturing processes could help lower costs for advanced-technology parts and components.

Competition with other zero-emission technologies - Transit agencies in many parts of the United States are implementing new technologies to make their operations more efficient and 
lower emissions. In states such as California, regulations are the primary driver for fleets transitioning to zero-emission bus technology. Early zero-emission bus demonstrations all involved FCEBs, primarily because the state of BEB technology at the time required overnight charging for a very limited range. Development of higher-energy-capacity traction battery designs improved significantly with the introduction of lithium-based batteries. The introduction of on-route charging and extended range batteries addressed concerns over lower range and long charge times. As a result, BEBs have made a surge into the market. Transit agencies all over the country have added or are planning to purchase BEBs. Both BEB and FCEB technologies are viable options to meet emission reduction goals. Aggressive marketing by OEMs that only produce BEBs fuels the current push for batteries over fuel cells. In contrast, the OEMs that produce FCEBs also produce buses powered by all possible propulsion systems. The large numbers of BEBs in the United States compared to lower FCEB numbers may lead to an assumption that one technology has an advantage over the other. The fact that deployments in Europe, Japan, and Korea are focused on FCEBs indicates there is a market for both.

\section{What's Expected for the 2018 Status Report}

This report includes data from two different FCEB bus designs-Van Hool and AFCB. NREL expects to monitor and evaluate several new demonstrations with funding from DOE and FTA. The addition of new FCEB designs and demonstration locations is expected to expand this annual assessment report's scope for determining the status of FCEB development.

In addition to the current FCEBs, the next-generation AFCB at SARTA in Canton, Ohio (with five to seven buses) is expected to be included in next year's assessment report.

NREL will include additional projects if sufficient data are available for the next report. 


\section{References and Related Reports}

Eudy, L., M. Post, and M. Jeffers. 2016. Fuel Cell Buses in U.S. Transit Fleets: Current Status 2016. NREL/TP-5400-67097. Golden, CO: National Renewable Energy Laboratory.

Müller, K., F. Schnitzeler, A. Lozanovski, S. Skiker, and M. Ojakovoh. 2017. CHIC Final

Report. Deliverable No. 5.3. Fuel Cells and Hydrogen Joint Undertaking. http://chicproject.eu/info-centre/publications. 


\section{Appendix: Summary Statistics}

Table A-1. Technology Readiness Levels for FCEB Commercialization

\begin{tabular}{|c|c|c|}
\hline $\begin{array}{l}\text { Technology } \\
\text { Readiness } \\
\text { Level }\end{array}$ & TRL Definition & Description \\
\hline TRL 9 & $\begin{array}{l}\text { Actual system operated } \\
\text { over the full range of } \\
\text { expected conditions }\end{array}$ & $\begin{array}{l}\text { The technology is in its final form. Deployment, marketing, } \\
\text { and support begin for the first fully commercial products. }\end{array}$ \\
\hline TRL 8 & $\begin{array}{l}\text { Actual system completed } \\
\text { and qualified through test } \\
\text { and demonstration }\end{array}$ & $\begin{array}{l}\text { The last step in true system development. Demonstration } \\
\text { of a limited production of } 50 \text { to } 100 \text { buses at a small } \\
\text { number of locations. Beginning the transition of all } \\
\text { maintenance to transit staff. }\end{array}$ \\
\hline TRL 7 & $\begin{array}{l}\text { Full-scale validation in } \\
\text { relevant environment }\end{array}$ & $\begin{array}{l}\text { A major step up from TRL } 6 \text { by adding larger numbers of } \\
\text { buses and increasing the hours of service. Full-scale } \\
\text { demonstration and reliability testing of } 5 \text { to } 10 \text { buses at } \\
\text { several locations. Manufacturers begin to train larger } \\
\text { numbers of transit staff in operation and maintenance. }\end{array}$ \\
\hline TRL 6 & $\begin{array}{l}\text { Engineering/pilot-scale } \\
\text { validation in relevant } \\
\text { environment }\end{array}$ & $\begin{array}{l}\text { First tests of prototype buses in actual transit service. } \\
\text { Field testing and design shakedown of } 1 \text { to } 2 \text { prototypes. } \\
\text { Manufacturers assist in operation and typically handle all } \\
\text { maintenance. Begin to introduce transit staff to } \\
\text { technology. }\end{array}$ \\
\hline TRL 5 & $\begin{array}{l}\text { Laboratory scale, similar } \\
\text { system validation in } \\
\text { relevant environment }\end{array}$ & $\begin{array}{l}\text { Integrated system is tested in a laboratory under } \\
\text { simulated conditions based on early modeling. System is } \\
\text { integrated into an early prototype or mule platform for } \\
\text { some on-road testing. }\end{array}$ \\
\hline TRL 4 & $\begin{array}{c}\text { Component and system } \\
\text { validation in laboratory } \\
\text { environment }\end{array}$ & $\begin{array}{l}\text { Basic technological components are integrated into the } \\
\text { system and begin laboratory testing and modeling of } \\
\text { potential duty cycles. }\end{array}$ \\
\hline TRL 3 & $\begin{array}{c}\text { Analytical and } \\
\text { experimental critical } \\
\text { function and/or proof of } \\
\text { concept } \\
\end{array}$ & $\begin{array}{l}\text { Active research into components and system integration } \\
\text { needs. Investigate what requirements might be met with } \\
\text { existing commercial components. }\end{array}$ \\
\hline TRL 2 & $\begin{array}{l}\text { Technology concept } \\
\text { and/or application } \\
\text { formulated }\end{array}$ & $\begin{array}{l}\text { Research technology needed to meet market } \\
\text { requirements. Define strategy for moving through } \\
\text { development stages. }\end{array}$ \\
\hline TRL 1 & $\begin{array}{l}\text { Basic principles observed } \\
\text { and reported }\end{array}$ & $\begin{array}{l}\text { Scientific research and early development of FCEB } \\
\text { concepts. }\end{array}$ \\
\hline
\end{tabular}




\section{AC Transit ZEBA Demonstration Summary}

Table A-2. AC Transit Data Summary

\begin{tabular}{|l|c|c|c|c|}
\hline & $\begin{array}{c}\text { ACT } \\
\text { ZEBA } \\
\text { All Data }\end{array}$ & $\begin{array}{c}\text { ACT } \\
\text { ZEBA } \\
\text { Past Year }\end{array}$ & $\begin{array}{c}\text { ACT Gillig } \\
\text { Diesel } \\
\text { All Data }\end{array}$ & $\begin{array}{c}\text { ACT Gillig } \\
\text { Diesel } \\
\text { Past Year }\end{array}$ \\
\hline Data period & $9 / 11-7 / 17$ & $8 / 16-7 / 17$ & $7 / 13-7 / 17$ & $8 / 15-7 / 16$ \\
\hline Number of buses & 13 & 13 & 10 & 10 \\
\hline Number of months & 63 & 12 & 49 & 12 \\
\hline Total miles & $1,916,871$ & 451,533 & $2,187,978$ & 473,199 \\
\hline Total fuel cell hours & 222,971 & 52,152 & - & - \\
\hline Average speed (mph) & 8.6 & 8.7 & - & - \\
\hline Average miles per month & 2,477 & 2,894 & 4,465 & 3,943 \\
\hline Number of scheduled days & 21,900 & 4,745 & 14,930 & 3,650 \\
\hline Number of days available & 16,499 & 3,777 & 13,289 & 3,335 \\
\hline Availability & $75 \%$ & $80 \%$ & $89 \%$ & $91 \%$ \\
\hline Fuel economy (miles per kg) & 5.72 & 5.07 & - & - \\
\hline Fuel economy (miles per dge) & 6.47 & 5.73 & 4.25 & 4.23 \\
\hline Bus MBRC & 4,715 & 8,210 & 6,671 & 6,067 \\
\hline Propulsion-related MBRC & 8,368 & 21,502 & 13,024 & 10,287 \\
\hline Fuel-cell-system-related MBRC & 23,741 & 30,102 & - & - \\
\hline Total hydrogen used (kg) & 304,341 & 87,207 & - & - \\
\hline SI Units & & & & \\
\hline Total kilometers & $3,084,905$ & 726,672 & $3,521,209$ & 761,540 \\
\hline Average speed (kph) & 13.8 & 13.9 & - & - \\
\hline Average km per month & 3,986 & 4,657 & 7,186 & 6,346 \\
\hline Fuel consumption (kg/100 km) & 10.86 & 12.26 & - & - \\
\hline Fuel consumption (L/100 km) & 33.05 & 40.20 & 55.66 & 55.92 \\
\hline Bus km between roadcalls (KBRC) & 7,588 & 13,213 & 10,736 & 9,764 \\
\hline Propulsion-related KBRC & 13,467 & 34,604 & 20,960 & 16,555 \\
\hline Fuel-cell-system-related KBRC & 38,207 & 48,444 & - & - \\
\hline
\end{tabular}




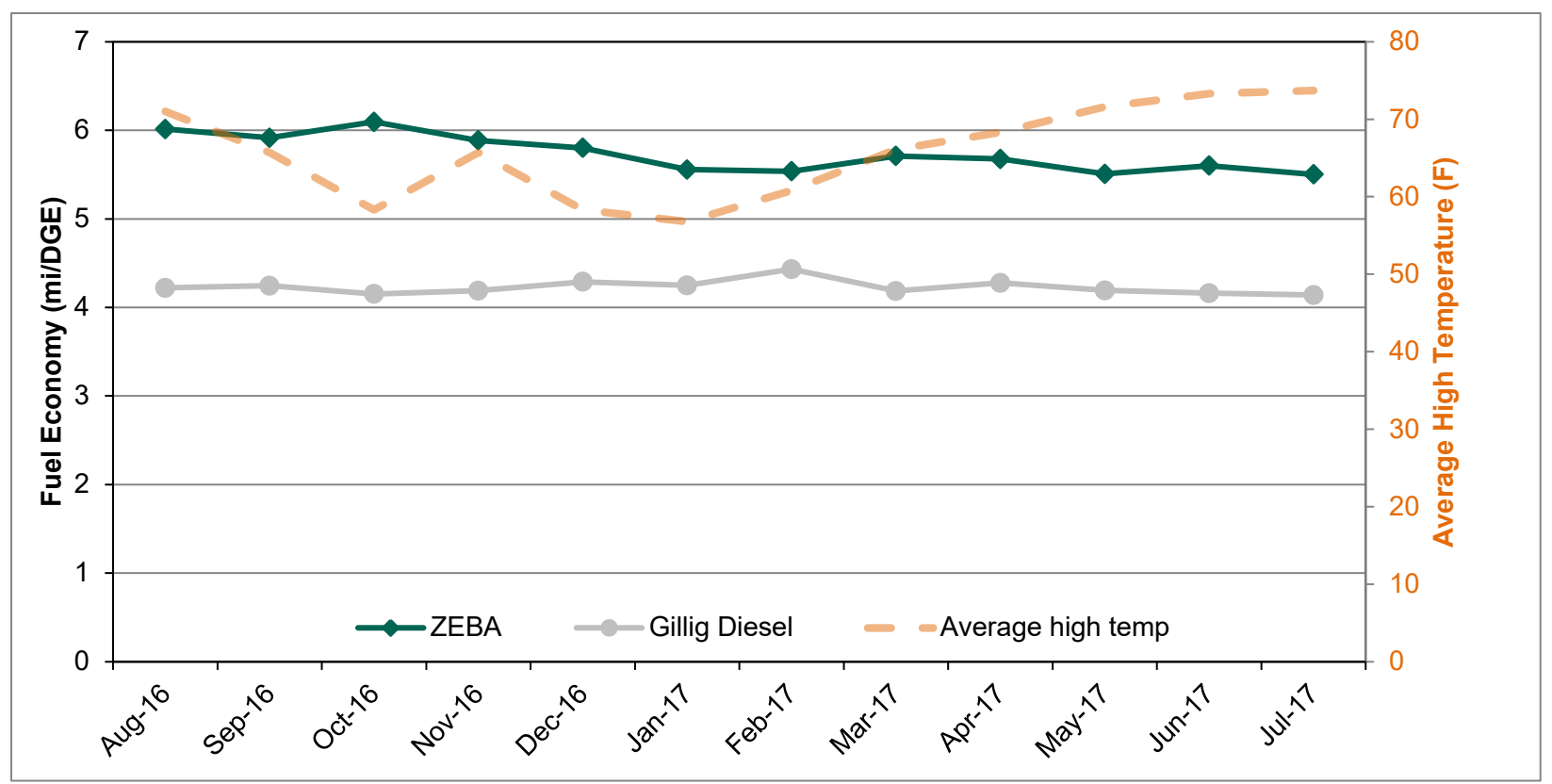

Figure A-1. Monthly fuel economy for the AC Transit ZEBA and diesel buses 


\section{SunLine AFCB Demonstration Summary}

Table A-3. SunLine Data Summary

\begin{tabular}{|l|c|c|c|c|c|}
\hline & $\begin{array}{c}\text { SL AFCB } \\
\text { All Data }\end{array}$ & $\begin{array}{c}\text { SL AFCB } \\
\text { Past Year }\end{array}$ & $\begin{array}{c}\text { SL Old } \\
\text { CNG } \\
\text { All Data }\end{array}$ & $\begin{array}{c}\text { SL Old } \\
\text { CNG } \\
\text { Past Year }\end{array}$ & $\begin{array}{c}\text { SL New } \\
\text { CNG } \\
\text { Past Year }\end{array}$ \\
\hline Data period & $3 / 12-7 / 17$ & $8 / 16-7 / 17$ & $3 / 12-12 / 16$ & $8 / 16-12 / 16$ & $1 / 17-7 / 17$ \\
\hline Number of buses & 4 & 4 & 5 & 5 & 5 \\
\hline Number of months & 65 & 12 & 58 & 5 & 7 \\
\hline Total miles & 386,587 & 105,826 & $1,369,822$ & 127,359 & 191,654 \\
\hline Total fuel cell hours & 19,833 & 8,580 & - & - & - \\
\hline Average speed (mph) & 13.6 & 12.3 & - & - & - \\
\hline Average miles per month & 2,517 & 2,205 & 4,724 & 4,218 & 5,476 \\
\hline Number of scheduled days & 4,124 & 1,165 & 13,547 & 680 & 944 \\
\hline Number of days available & 3,031 & 847 & 11,948 & 596 & 844 \\
\hline Availability & $73 \%$ & $73 \%$ & $88 \%$ & $88 \%$ & $89 \%$ \\
\hline Fuel economy (miles per kg or gge ${ }^{\text {a) }}$ & 5.65 & 5.32 & 2.88 & 2.88 & 3.37 \\
\hline Fuel economy (miles per dge) & 6.38 & 6.02 & 3.21 & 3.22 & 3.77 \\
\hline Bus MBRC & 4,602 & 4,601 & 9,012 & 8,491 & 63,885 \\
\hline Propulsion-related MBRC & 6,552 & 5,291 & 23,217 & 15,920 & 95,827 \\
\hline Fuel-cell-system-related MBRC & 14,318 & 10,583 & - & - & - \\
\hline Total hydrogen used (kg) & 66,199 & 18,892 & - & - & - \\
\hline SI Units & & & & & \\
\hline Total kilometers & 622,151 & 170,310 & $2,204,515$ & 204,964 & 308,437 \\
\hline Average speed (kph) & 31.4 & 19.8 & - & - & - \\
\hline Average km per month & 4,051 & 3,549 & 7,603 & 6,788 & 8,813 \\
\hline Fuel consumption (kg/100 km) & 11.00 & 11.68 & - & - & - \\
\hline Fuel consumption (L/100 km) & 35.64 & 37.16 & 73.70 & 73.47 & 62.75 \\
\hline Bus km between roadcalls (KBRC) & 2,860 & 2,859 & 5,600 & 5,276 & 39,696 \\
\hline Propulsion-related KBRC & 4,071 & 3,288 & 14,426 & 9,892 & 59,544 \\
\hline Fuel-cell-system-related KBRC & 8,897 & 6,576 & - & - & - \\
\hline
\end{tabular}

${ }^{a}$ gasoline gallon equivalent 


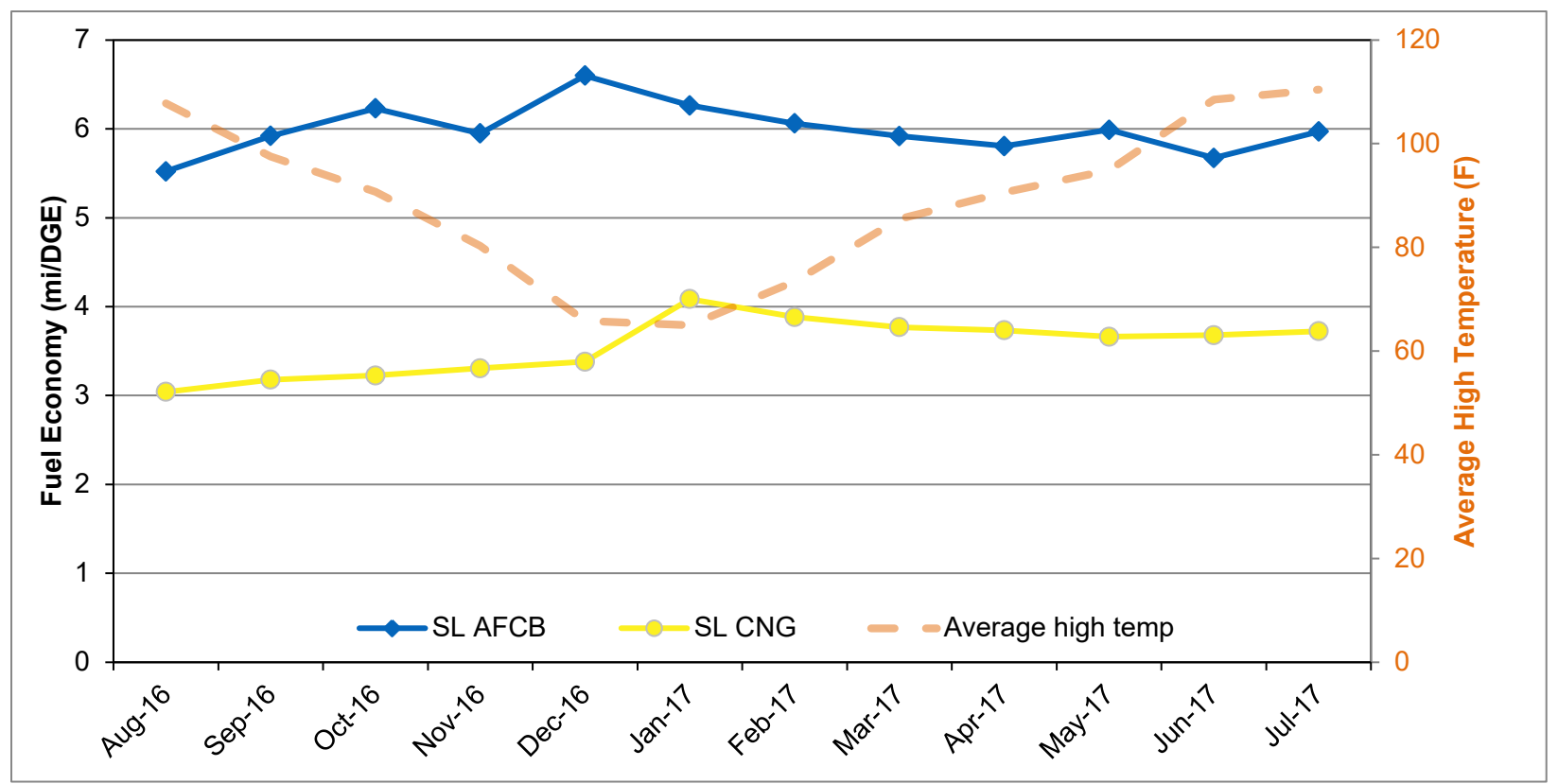

Figure A-2. Monthly fuel economy for the SunLine AFCBs and CNG buses 


\section{UCI AFCB Demonstration Summary}

Table A-4. UCI Data Summary

\begin{tabular}{|l|c|c|}
\hline & $\begin{array}{c}\text { UCI AFCB } \\
\text { All Data }\end{array}$ & $\begin{array}{c}\text { UCI AFCB } \\
\text { Past Year }\end{array}$ \\
\hline Data period & $1 / 16-7 / 17$ & $8 / 16-7 / 17$ \\
\hline Number of buses & 1 & 1 \\
\hline Number of months & 19 & 12 \\
\hline Total miles & 43,693 & 25,422 \\
\hline Total fuel cell hours & 2,700 & 2,626 \\
\hline Average speed (mph) & 9.4 & 9.7 \\
\hline Average miles per month & 2,300 & 2,119 \\
\hline Number of scheduled days & 408 & 251 \\
\hline Number of days available & 366 & 226 \\
\hline Availability & $90 \%$ & $90 \%$ \\
\hline Fuel economy (miles per kg or gge) & 5.17 & 5.19 \\
\hline Fuel economy (miles per dge) & 5.84 & 5.86 \\
\hline Bus MBRC & 8,739 & 25,422 \\
\hline Propulsion-related MBRC & 10,923 & $\mathrm{a}$ \\
\hline Fuel-cell-system-related MBRC & 21,847 & $\mathrm{~b}$ \\
\hline Total hydrogen used (kg) & 8,263 & 4,862 \\
\hline SI Units & & \\
\hline Total kilometers & 70,317 & 40,913 \\
\hline Average speed (kph) & 26.0 & 15.6 \\
\hline Average km per month & 3,701 & 3,410 \\
\hline Fuel consumption (kg/100 km) & 12.02 & 11.97 \\
\hline Fuel consumption (L/100 km) & 39.36 & 39.81 \\
\hline Bus km between roadcalls (KBRC) & 14,064 & 40,913 \\
\hline Propulsion-related KBRC & 17,579 & $\mathrm{a}$ \\
\hline Fuel-cell-system-related KBRC & 35,159 & $\mathrm{~b}$ \\
\hline
\end{tabular}

a There were no propulsion-related roadcalls during the data period.

b There were no fuel-cell-system-related roadcalls during the data period. 


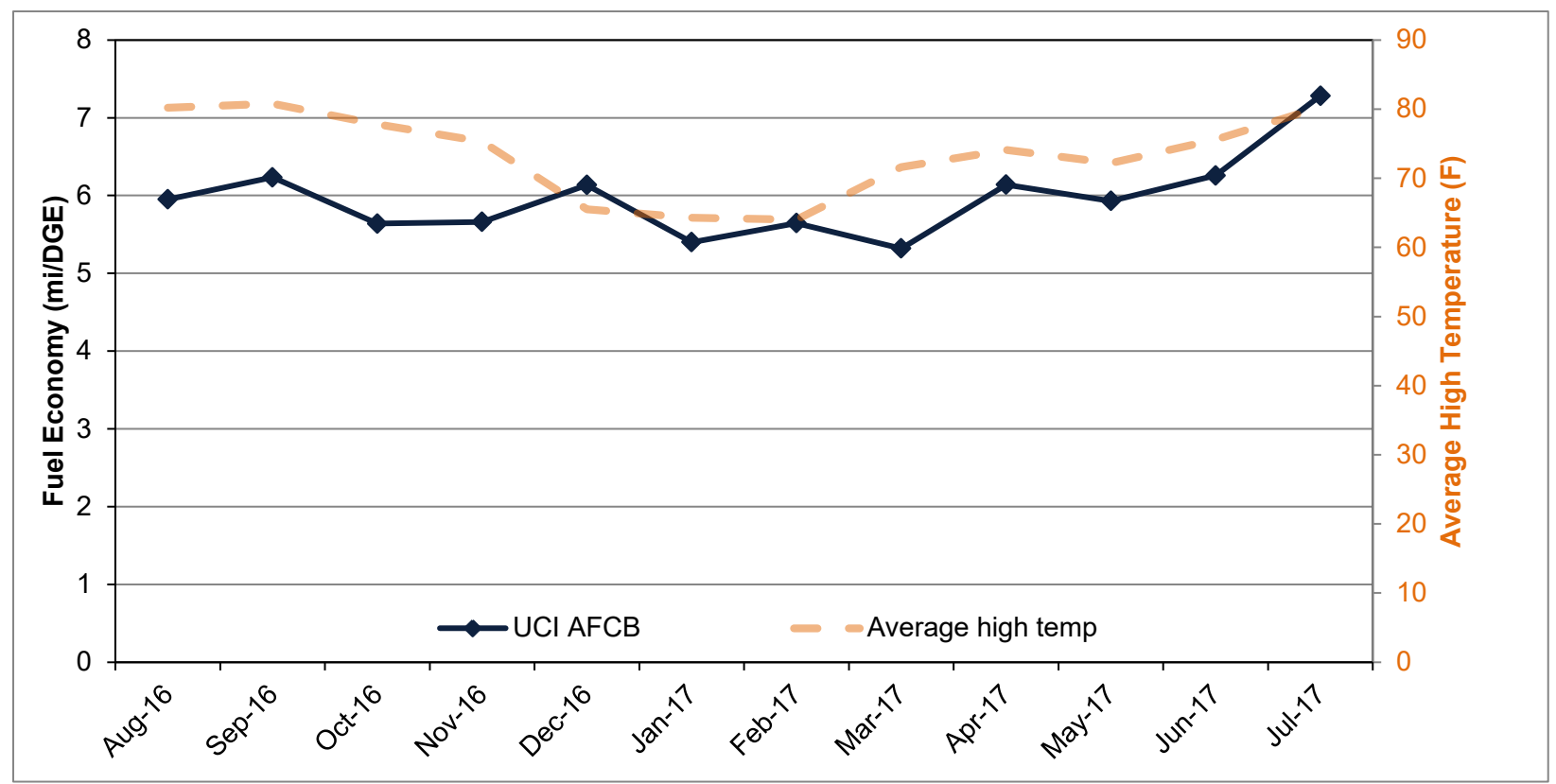

Figure A-3. Monthly fuel economy for the UCI AFCB 
OCTA AFCB Demonstration Summary

Table A-5. OCTA Data Summary

\begin{tabular}{|l|c|c|c|c|}
\hline & $\begin{array}{c}\text { OCTA } \\
\text { AFCB All } \\
\text { Data }\end{array}$ & $\begin{array}{c}\text { OCTA } \\
\text { AFCB Past } \\
\text { Year }\end{array}$ & $\begin{array}{c}\text { OCTA } \\
\text { CNG } \\
\text { All Data }\end{array}$ & $\begin{array}{c}\text { OCTA } \\
\text { CNG Past } \\
\text { Year }\end{array}$ \\
\hline Data period & $6 / 16-7 / 17$ & $8 / 16-7 / 17$ & $5 / 16-7 / 17$ & $8 / 16-7 / 17$ \\
\hline Number of buses & 1 & 1 & 10 & 10 \\
\hline Number of months & 14 & 12 & 15 & 12 \\
\hline Total miles & 15,322 & 12,008 & 462,070 & 384,274 \\
\hline Total fuel cell hours & 1,252 & 994 & - & - \\
\hline Average speed (mph) & 12.2 & 12.1 & - & - \\
\hline Average miles per month & 1,094 & 1,001 & 3,080 & 3,202 \\
\hline Number of scheduled days & 457 & 365 & - & - \\
\hline Number of days available & 191 & 130 & - & - \\
\hline Availability & $42 \%$ & $36 \%$ & - & - \\
\hline Fuel economy (miles per kg or gge) & 6.68 & 6.71 & 3.61 & 3.62 \\
\hline Fuel economy (miles per dge) & 7.54 & 7.59 & 4.03 & 4.05 \\
\hline Bus MBRC & 1,306 & 1,201 & 20,090 & 30,032 \\
\hline Propulsion-related MBRC & 1,543 & 1,501 & 42,006 & 56,727 \\
\hline Fuel-cell-system-related MBRC & 8,488 & 6,004 & - & - \\
\hline Total hydrogen used (kg) & 2,114 & 1,608 & - & - \\
\hline SI Units & & & & \\
\hline Total kilometers & 24,658 & 19,325 & 743,630 & 618,429 \\
\hline Average speed (kph) & 19.7 & 19.4 & - & - \\
\hline Average km per month & 1,761 & 1,611 & 4,957 & 5,153 \\
\hline Fuel consumption (kg/100 km) & 9.30 & 9.26 & & \\
\hline Fuel consumption (L/100 km) & 28.72 & 27.87 & 58.70 & 58.41 \\
\hline Bus km between roadcalls (KBRC) & 2,102 & 1,933 & 32,332 & 48,332 \\
\hline Propulsion-related KBRC & 2,483 & 2,416 & 67,602 & 91,293 \\
\hline Fuel-cell-system-related KBRC & 13,660 & 9,663 & - & - \\
\hline & & & & - \\
\hline
\end{tabular}




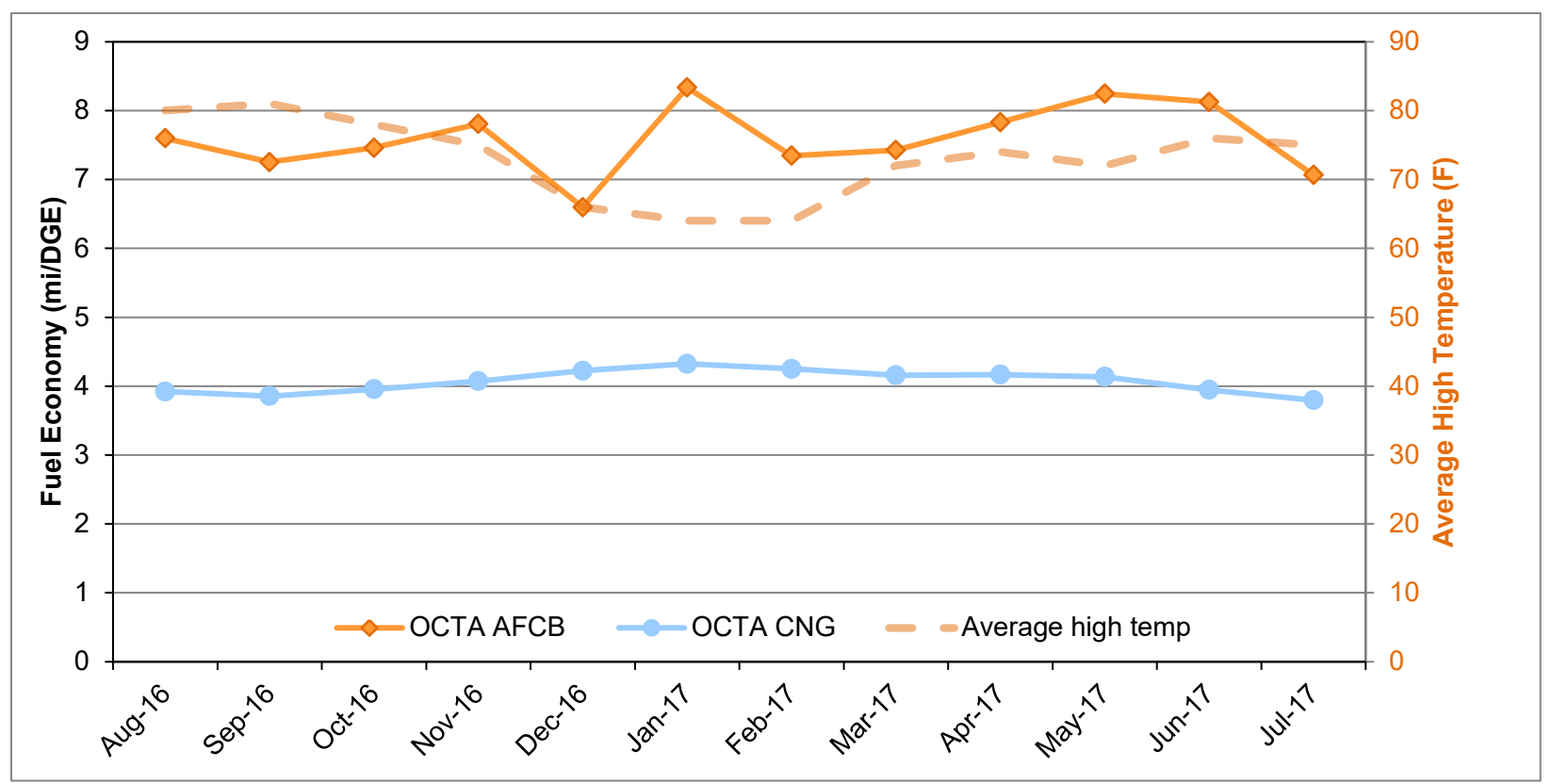

Figure A-4. Monthly fuel economy for the OCTA AFCB

This report is available at no cost from the National Renewable Energy Laboratory at www.nrel.gov/publications. 


\section{MBTA AFCB Demonstration Summary}

Data items that are not yet available are marked as N/A.

Table A-6. MBTA Data Summary

\begin{tabular}{|l|c|}
\hline & $\begin{array}{c}\text { MBTA } \\
\text { AFCB All } \\
\text { Data }\end{array}$ \\
\hline Data period & $11 / 16-7 / 17$ \\
\hline Number of buses & 1 \\
\hline Number of months & 9 \\
\hline Total miles & 4,957 \\
\hline Total fuel cell hours & 599 \\
\hline Average speed (mph) & 8.3 \\
\hline Average miles per month & 601 \\
\hline Number of scheduled days & N/A \\
\hline Number of days available & N/A \\
\hline Availability & N/A \\
\hline Fuel economy (miles per kg or gge) & 4.30 \\
\hline Fuel economy (miles per dge) & 4.86 \\
\hline Bus MBRC & N/A \\
\hline Propulsion-related MBRC & N/A \\
\hline Fuel-cell-system-related MBRC & N/A \\
\hline Total hydrogen used (kg) & 1,144 \\
\hline SI Units & \\
\hline Total kilometers & 7,978 \\
\hline Average speed (kph) & 13.3 \\
\hline Average km per month & 967 \\
\hline Fuel consumption (kg/100 km) & 14.45 \\
\hline Fuel consumption (L/100 km) & 48.03 \\
\hline Bus km between roadcalls (KBRC) & N/A \\
\hline Propulsion-related KBRC & N/A \\
\hline Fuel-cell-system-related KBRC & N/A \\
\hline
\end{tabular}

